\title{
Recent developments in copper nanoparticle-catalyzed synthesis of 1,4-disubstituted 1,2,3-triazoles in water
}

\author{
Kashmiri Lal* and Poonam Rani \\ Department of Chemistry, Guru Jambheshwar University of Science and Technology, Hisar-125 \\ 001, Haryana, India \\ E-mail:klal_iitd@yahoo.com
}

DOI: http://dx.doi.org/10.3998/ark.5550190.p009.593

\begin{abstract}
The $\mathrm{Cu}(\mathrm{I})$-catalyzed 1,3-dipolar cycloaddition between terminal alkynes and organic azides generating 1,4-disubstituted 1,2,3-triazoles has attracted considerable attention owing to its consistency, specificity, and biocompatibility. Copper nanoparticles supported on various supports such as agarose, cellulose, chitosan, charcoal, activated carbon, silica gel, aminoclay, polymer support like poly(styrene-co-maleimide) (SMI) and polyvinylpyrrolidone (PVP) have been utilized as heterogeneous catalyst for the synthesis of 1,2,3-triazoles. This review summarizes various straightforward and efficient methods for the regioselective synthesis of 1,4disubstituted 1,2,3-triazoles utilizing supported copper nanoparticles as a source of the heterogeneous catalytic species and water as solvent.
\end{abstract}

Keywords: Click chemistry; copper nanoparticles; 1,4-disubstituted 1,2,3-triazoles; green chemistry; heterogeneous catalysis

\section{Table of Contents}

1. Introduction

2. Copper Nanoparticle-catalyzed Synthesis of 1,4-Disubstituted 1,2,3-Triazoles

2.1 One-pot synthesis of 1,4-disubstituted 1,2,3-triazoles from in situ generated organic azides

2.2 Synthesis of 1,4-disubstituted 1,2,3-triazoles from preformed organic azides

3. Conclusions

4. Abbreviations

5. References 


\section{Introduction}

The term click chemistry was first coined by Kolb, Finn, and Sharpless in a review article published in 2001. ${ }^{1}$ Click chemistry includes extremely exothermic bond formations such as cycloaddition reactions, nucleophilic ring opening, addition reactions to carbon-carbon multiple bonds and non-aldol-type carbonyl reactions. ${ }^{2}$ The $\mathrm{Cu}(\mathrm{I})$-catalyzed $[3+2]$ azide alkyne cycloaddition reaction (CuAAC) reported by the group of Sharpless ${ }^{3}$ and Meldal ${ }^{4}$ is one of the most reliable click reactions has been used synonymously with click chemistry in recent literature (Scheme 1) ${ }^{5-7}$ It transforms terminal alkyne and organic azide exclusively into the corresponding 1,4-disubstituted 1,2,3-triazole. This metal catalyzed method has many benefits over Huisgen cycloaddition reactions of azide with terminal alkyne. ${ }^{8-10}$ The latter technique yields a mixture of 1,4- and 1,5-regioisomers. Further, the reaction required a strong electronwithdrawing substituent either on azide or on alkyne under high temperature $\left(80-120{ }^{\circ} \mathrm{C}\right)$ and prolonged reaction period. ${ }^{11}$

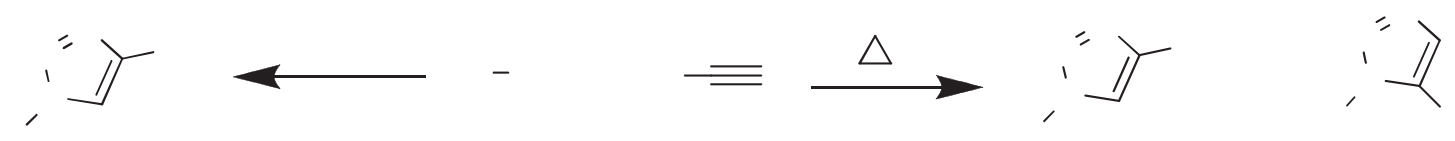

Scheme 1. Thermal and copper catalyzed Huisgen cycloaddition between azide with terminal alkyne.

Moreover, this click reaction is associated with a number of benefits including great efficiency, regioselectivity, and compatibility with reaction conditions. The special property of the 1,4-disubstituted 1,2,3-triazole ring in terms of its capability to participate in hydrogen bond and dipole-dipole interactions has made click chemistry even more useful for a variety of applications. $^{12}$

1,2,3-Triazoles are main class of heterocycles because of their extensive range of biological properties such as antimicrobial, ${ }^{13}$ anticancer, ${ }^{14}$ antitubercular, ${ }^{15}$ anti-HIV,${ }^{16}$ antimalarial, ${ }^{17}$ antibacterial,${ }^{18}$ antifungal, ${ }^{19}$ antiviral, ${ }^{20}$ antiepileptic, ${ }^{21}$ antidiabetic ${ }^{22}$ and antiallergic behavior. ${ }^{23}$ They are also used as optical brighteners,${ }^{24}$ light stabilizers, ${ }^{25}$ fluorescence chemosensors,${ }^{26}$ and corrosion retarding agents. ${ }^{27}$

Because of increasing anxiety about environmental effects, great efforts have been made towards the improvement of green chemistry that decreases pollution in chemical synthesis. For these purposes development of new heterogeneous and recyclable catalysts, the use of ecobenign solvents and the coupling of three or more components in a single step are vital and exciting issues in green chemistry. ${ }^{2}$ The use of water as an economical and safer solvent has 
many advantages over expensive, combustible and toxic organic solvents, diminishing atmospheric pollution. In addition, conducting the reaction in aqueous media allows easy phase separation of products because most of the organic compounds are not soluble in water. ${ }^{28}$

Nanomaterials have aroused much attention in current times because of their interesting properties dissimilar from those of their corresponding bulk materials. ${ }^{29}$ Metal nanoparticles have received importance as dynamic catalysts for various organic conversions. ${ }^{30,31}$ In particular, copper nanoparticles, owing to its price effectiveness, has gained very good impact mainly in the areas of catalysis and biology. ${ }^{32}$ In recent years there has also been increasing interest in using environmentally benign, economical, easily available and strong support/stabilizer materials for the synthesis of metal nanoparticles.

A number of homogeneous copper catalysts have been employed for the click reaction of azides and alkynes. ${ }^{33-37}$ In spite of the high selectivity, important productivity, improved yield and simplicity of optimization of the reported homogeneous catalysts, they suffer from the difficulty of separating the copper catalyst from the products, which produces environmental barriers to broadening their scope, thus limiting their extensive use in a number of applications. Elimination of trace quantities of catalyst from the end product is important because metal contamination can cause toxicity, especially in the pharmaceutical industry. Even with the careful use of many methods such as distillation or chromatography, the extraction or elimination of trace amounts of catalyst remains a challenge. In order to solve this problem, chemists have investigated a best strategy; the use of a heterogeneous catalyst for the preparation of 1,2,3triazoles. ${ }^{38-40}$ A review article published in Accounts of Chemical Research has documented the literature reporting the use of copper nanoparticles in synthesis of 1,2,3-triazoles. ${ }^{41}$

The heterogenization of click catalysts is an attractive alternative, due to the benefits of easy removal, recovery and reusability that it offers. Immobilization of catalysts on solid supports is one of the best methods to improve the efficiency and recovery of catalyst. Heterogenization has been achieved by the covalent and non-covalent immobilization of copper species onto a number of supports such as activated carbon, ${ }^{42}$ zeolites, $^{43}$ titanium oxide, ${ }^{44}$ alumina, ${ }^{45}$ aluminium oxyhydroxide fibers, ${ }^{46}$ silica, ${ }^{47-48}$ crosslinked poly(ethyleneimine), ${ }^{49}$ basic Amberlyst, ${ }^{48}$ Tentagel resin, ${ }^{51}$ ionic polymers, ${ }^{52}$ biopolymers ${ }^{53}$ and carbon nantotubes. ${ }^{54}$

In some of these heterogeneous catalysts, the immobilization of amine-based ligands with a contrasted ability as homogeneous click mediators for the synergetic exploitation of their $\mathrm{Cu}$ (I) chelating capabilities and base character has demonstrated to be an efficient approach for the design of such hybrid materials. In particular dimethyl aminomethyl, ${ }^{50}$ tris[(1-benzyl-1H-1,2,3triazol-4-yl)methyl]amine (TBTA), ${ }^{51} 3$-aminopropyl, ${ }^{47} 3$-[(2-aminoethyl)amino]propyl ${ }^{47}$ and 1,5,7-triazabicyclo[4.4.0]dec-5-ene (TBD) ${ }^{48}$ have been used as chelating frameworks by their grafting onto a polystyrene matrix or silica.

Magnetic heterogeneous catalysts also constitute an excellent choice. Magnetic nano-sized particles $^{55-58}$ have recently been industrialized as promising supports for immobilization with applications in catalytic transformations as strong, readily available and high-surface area heterogeneous catalysts. Further, they have the advantage of being magnetically recoverable by 
an external permanent magnet, thereby facilitating the catalyst separation after the reaction, so avoiding time-consuming and difficult separation steps and allowing for practical continuous catalysis. In addition, these catalysts can be used under aqueous conditions to give the desired products in very brief reaction times and high yields. ${ }^{59}$ The present review will focus on the literature with applications of copper nanoparticles in the CuAAC for the synthesis of various 1,4-disubstituted 1,2,3-triazole derivatives utilizing only water as the solvent system.

\section{Copper Nanoparticle-catalyzed Synthesis of 1,4-Disubstituted 1,2,3- Triazoles}

This section involves the one-pot multicomponent reactions for the synthesis of 1,4-disubstituted 1,2,3-triazoles utilizing in situ-generated organic azides as well as the cycloaddition reaction between organic azides and terminal alkynes.

\subsection{One-pot synthesis of 1,4-disubstituted 1,2,3-triazoles from in situ generated organic azides}

One pot regeoselective synthesis of 1,4-disubstituted 1,2,3-triazoles (1) using alumina-supported copper nanoparticles $\left(\mathrm{Cu}-\mathrm{Al}_{2} \mathrm{O}_{3}\right)$ as a heterogeneous catalyst was described by Kantam et al. (Scheme 2). ${ }^{60}$ The catalyst was prepared from $\mathrm{Cu}(\mathrm{II})$ acetyl acetonate and aluminium isopropoxide precursors using an aerogel protocol. Further, the performance of the catalyst was fully retained after reuse up to four times. The catalyst was identified by XRD, TEM, XPS, AI MAS NMR and ICP-AES.

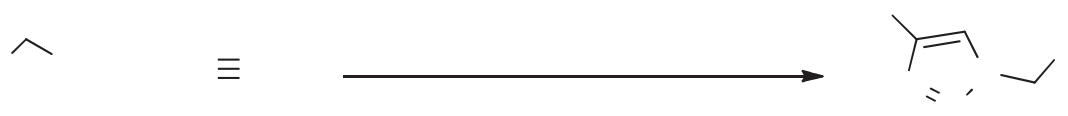

Scheme 2. $\mathrm{Cu} / \mathrm{Al}_{2} \mathrm{O}_{3}$ catalyzed one pot $\mathrm{CuAAC}$ reaction for the regioselective formation of 1,4disubstituted 1,2,3-triazoles in water.

Sharghi et al. synthesized copper nanoparticles supported on charcoal for multicomponent catalytic formation of 1,2,3-triazole (2) derivatives from benzyl halides or alkyl halides, terminal alkynes and sodium azide using water (Scheme 3). ${ }^{61}$ This copper catalyst immobilized on 
activated carbon exhibits an excellent catalytic performance and 1,4-regioselectivity for 1,3dipolar Huisgen cycloaddition reaction for the construction of 1,2,3-triazole framework. This method avoids the handling of organic azides as they are generated in situ and has a broad practical scope for the preparation of new azacrown ether and anthraquinone derivatives of triazole. SEM, AFM, XRD, FT-IR and ICP were used to characterize the $(\mathrm{Cu} / \mathrm{C})$ heterogeneous catalyst. The catalyst can be repeatedly used ten times without significant loss of catalytic activity and subsequently recovered after the reaction.

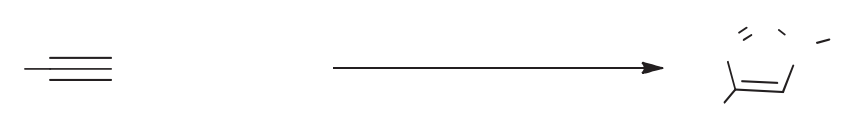

Scheme 3. Triazole synthesis via copper nanoparticles supported on charcoal.

Shargi et al. reported an effective, regioselective, one-pot synthesis of $\beta$-hydroxytriazole (3) from sodium azide, epoxide, and non-activated terminal alkyne by a three-component click reaction, via the formation of 2-azido alcohol from sodium azide and epoxide (Scheme 4). ${ }^{62}$ This nontoxic, mild and eco-friendly reaction was achieved in the presence of $\mathrm{T}(\mathrm{o}-\mathrm{Cl}) \mathrm{PPCu}-$ AMWCNT heterogeneous catalyst in the absence of any additives at ambient temperature in water as a green solvent. The catalyst was prepared by Immobilization of [meso-tetrakis $(o$ chlorophenyl)porphyrinato] $\mathrm{Cu}$ (II) nanoparticles onto activated multi-walled carbon nanotubes (AMWCNT). Further, the results revealed that the catalyst was recovered by separation after every experiment and could be recycled for the 1,2,3-triazole synthesis in more than ten consecutive reactions. Likewise the catalyst was identified by SEM, TEM, AFM, XRD, TG and ICP analysis.

Alonso et al. presented a new heterogeneous catalyst consisting of oxidized copper nanoparticles on activated carbon for the multicomponent Huisgen 1,3-dipolar cycloaddition from different azide precursors, including organic halide, diazonium salt, epoxide, aniline or alkene in water (Scheme 5). ${ }^{63}$ A promising route for one-pot transformation of carbon-carbon double bonds into triazoles bearing a versatile methylsulfanyl group is also described. The catalyst can be easily recovered by filtration and reused leading to triazoles (4) in quantitative yield along five consecutive cycles. According to ICP-MS analysis, no leaching of copper was detected after the fifth cycle. 


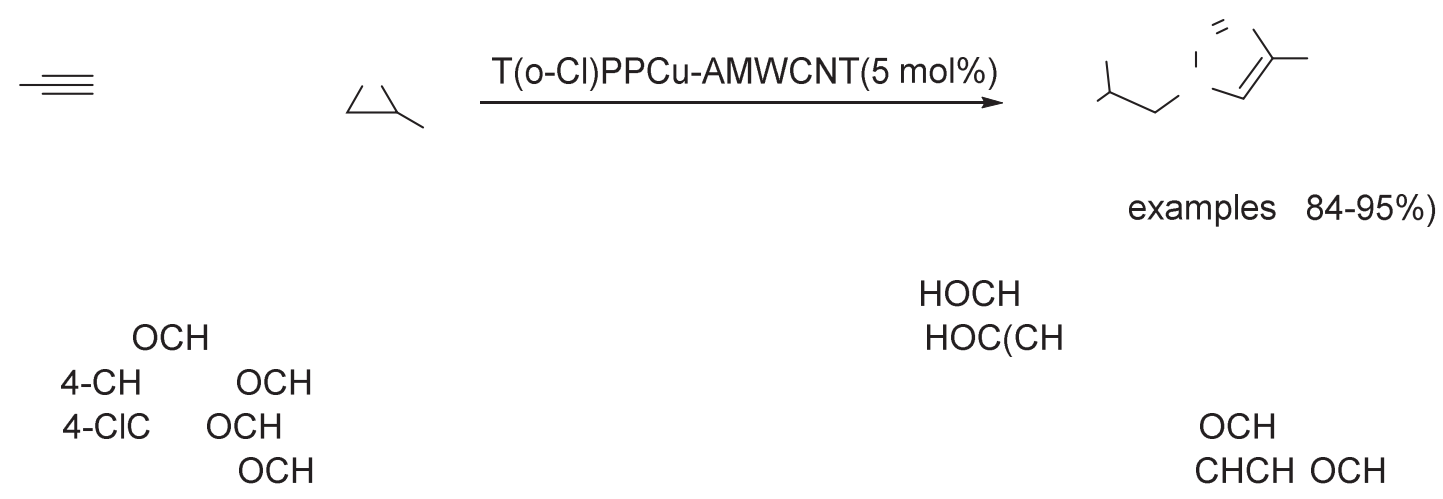

Scheme 4. Synthesis of $\beta$-hydroxy-1,4-disubstituted 1,2,3-triazoles using AMWCNT-supported $\mathrm{T}(\mathrm{o}-\mathrm{Cl}) \mathrm{PPCu}$ catalyst.
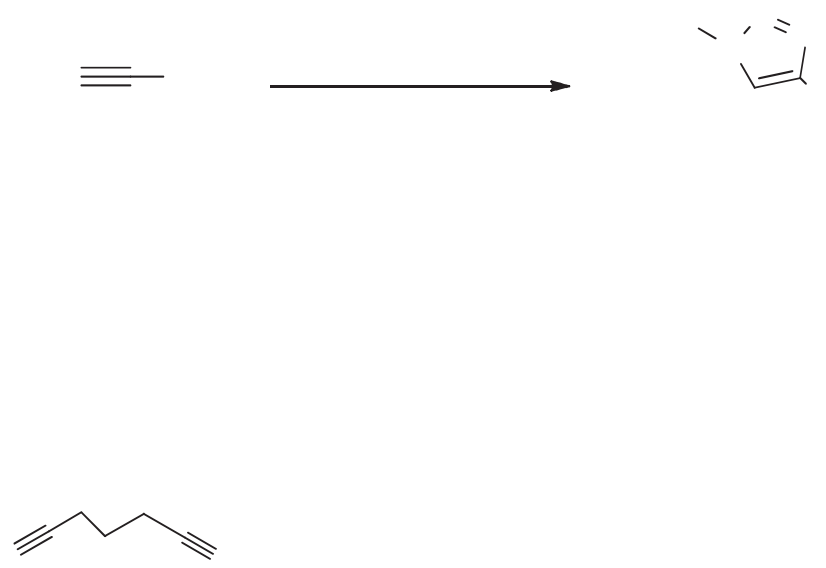

Scheme 5. Click reaction catalyzed by CuNPs/C using organic halides.

Wang et al. developed supported $\mathrm{Cu}(\mathrm{II})$ catalysts [imidazolium-loaded Merrifield resinsupported copper (Cu-PSIL) and cross-linked polymeric ionic liquid material-supported copper (Cu-CPSIL)] and used for the one-pot synthesis of 1,4-disubstituted 1,2,3-triazoles (5) without using a reducing agent (Scheme 6) ${ }^{64} \mathrm{Cu}$-PSIL was derived from $\mathrm{CuI}$ and imidazolium-loaded polymeric support PSIL. The catalytic performance of the heterogeneous $\mathrm{CuO} / \mathrm{SiO}_{2}$ catalyst prepared by a precipitation-gel method was also investigated. The study indicated that the three supports acted as ligands stabilizing the copper particles. This reaction system avoids the handling of organic azides, as they are produced in situ, making this already dominant click process even more user-friendly and nontoxic. High yields of 1,2,3-triazoles were neatly synthesized in water at room temperature by both catalysts and reused for a number of times without major detriment to activity. Based on XPS, IR and ESI-MS characterizations, it was proposed that the alkyne-alkyne homocoupling proceed on the $\mathrm{Cu}$ (II) site to form the 
catalytically active $\mathrm{Cu}(\mathrm{I})$ species and the cycloaddition proceeded over the active $\mathrm{Cu}(\mathrm{I})$ species generated.

Alonso et al. described copper nanoparticles on activated carbon as modest and proficient catalyst for the synthesis of $\beta$-hydroxy-1,2,3-triazoles (6) from various epoxides and alkynes in water. The catalyst remained reusable at a low copper loading for five cycles without any significant loss of catalytic activity (Scheme 7). ${ }^{64}$ The study found that the catalyst was handled in air and all of the experiments were carried out without air exclusion. The regio- and stereochemistry of the reaction was studied by X-ray crystallographic analysis.
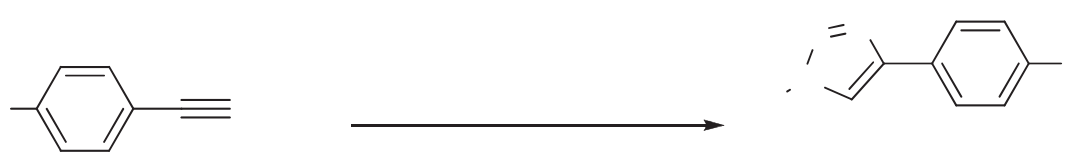

Scheme 6. The one-pot direct synthesis of 1,2,3-triazoles catalyzed by supported $\mathrm{Cu}(\mathrm{II})$ catalysts $\mathrm{Cu}-\mathrm{CPSIL}$ (A), Cu-PSIL (B) and $\mathrm{CuO} / \mathrm{SiO}_{2}(\mathrm{C})$.

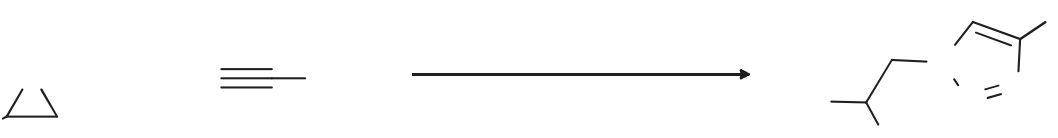

Scheme 7. One-pot multicomponent copper nanoparticles catalyzed click synthesis of $\beta$-hydroxy-1,2,3-triazoles from epoxides and alkynes. 
In a smart approach, Alonso et al. developed a reusable heterogeneous catalyst by immobilization of oxidized copper nanoparticles on activated carbon. The catalyst was used in the multicomponent synthesis of 1,2,3-triazoles (7) from organic halides, diazonium salts, and aromatic amines in water (Scheme 8). ${ }^{66}$ The product was easily isolated and does not require purification. The reported catalyst was better than other heterogeneous copper catalysts and apparently works under heterogeneous conditions.

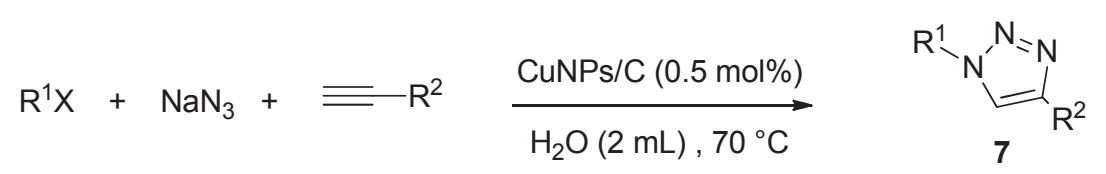

( 11 examples, $76-99 \%$ )

7a: $\mathrm{R}^{1}=4-\mathrm{CNC}_{6} \mathrm{H}_{4} \mathrm{CH}_{2^{-}}, \mathrm{R}^{2}=\mathrm{C}_{6} \mathrm{H}_{5^{-}}, \mathrm{X}=\mathrm{Br}, 99 \%$

7b: $\mathrm{R}^{1}=2,4-\mathrm{OCH}_{3} \mathrm{C}_{6} \mathrm{H}_{3} \mathrm{CH}_{2^{-}}, \mathrm{R}^{2}=\mathrm{C}_{6} \mathrm{H}_{5^{-}}, \mathrm{x}=\mathrm{Br}, 98 \%$

7c: $\mathrm{R}^{1}=\mathrm{C}_{6} \mathrm{H}_{5} \mathrm{CHCHCH}_{2^{-}}, \mathrm{R}^{2}=\mathrm{C}_{6} \mathrm{H}_{5^{-}}, \mathrm{X}=\mathrm{Br}, 94 \%$

7d: $\mathrm{R}^{1}=\mathrm{C}_{2} \mathrm{H}_{5} \mathrm{COOCH}_{2^{-}}, \mathrm{R}^{2}=\mathrm{C}_{6} \mathrm{H}_{5^{-}}, \mathrm{X}=\mathrm{Br}, 98 \%$

7e: $\mathrm{R}^{1}=\mathrm{C}_{6} \mathrm{H}_{5} \mathrm{CH}_{2}^{-}$, Alkyne $=\mathrm{X}=\mathrm{Br}, 87 \%$

7f: $\mathrm{R}^{1}=\mathrm{C}_{6} \mathrm{H}_{5} \mathrm{CH}_{2^{-}}, \mathrm{R}^{2}=\mathrm{C}_{6} \mathrm{H}_{5^{-}}, \mathrm{X}=\mathrm{Cl}, 99 \%$ 7g: $\mathrm{R}^{1}=\mathrm{C}_{6} \mathrm{H}_{5} \mathrm{CH}_{2^{-}}, \mathrm{R}^{2}=\left(\mathrm{CH}_{3}\right)_{3} \mathrm{Si}-, \mathrm{X}=\mathrm{Br}, 82 \%$

7h: $\mathrm{R}^{1}=\mathrm{C}_{6} \mathrm{H}_{5^{-}}, \mathrm{R}^{2}=\mathrm{C}_{6} \mathrm{H}_{5} \mathrm{OCH}_{2^{-}}, \mathrm{X}=\mathrm{Br}, 76 \%$

7i: $\mathrm{R}^{1}=\mathrm{CH}_{3}\left(\mathrm{CH}_{2}\right)_{7} \mathrm{CH}_{2^{-}}, \mathrm{R}^{2}=\mathrm{C}_{6} \mathrm{H}_{5^{-}}, \mathrm{X}=\mathrm{Cl}, 94 \%$; $X=1,98 \%$

7j: $\mathrm{R}^{1}=\mathrm{C}_{6} \mathrm{H}_{5} \mathrm{CH}_{2^{-}}, \mathrm{R}^{2}=\mathrm{C}_{6} \mathrm{H}_{5^{-}}, \mathrm{X}=\mathrm{I}, 98 \%$, $\mathrm{X}=\mathrm{Br}, 98 \%$

7k: $\mathrm{R}^{1}=\mathrm{C}_{6} \mathrm{H}_{5} \mathrm{COCH}_{2^{-}}, \mathrm{R}^{2}=\mathrm{C}_{6} \mathrm{H}_{5^{-}}, \mathrm{X}=\mathrm{Br}, 98 \%$, $\mathrm{X}=\mathrm{Cl}, 82 \%$

Scheme 8. Multicomponent synthesis of 1,2,3-triazoles.

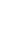
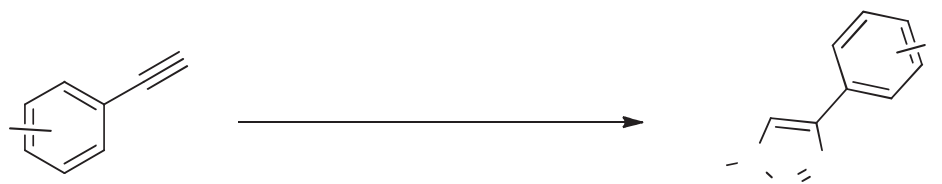

Scheme 9. One-pot synthesis of 1,4-disubstituted 1,2,3-triazoles.

Wan and Cai developed silica-immobilized $\mathrm{NHC}-\mathrm{Cu}(\mathrm{I})$ catalyst for an efficient and green one-pot synthesis of 1,4-disubstituted 1,2,3-triazoles $(\mathbf{8})$ from halides, sodium azide and aromatic 
alkynes. ${ }^{67}$ The reactions progressed smoothly to furnish corresponding products in high yields (Scheme 9). In addition, the catalyst could be easily recovered and reused for six rounds without significant loss of activity. The catalyst showed 1,4-regioselectivity for the [3,2]-Huisgen cycloaddition in water as a green solvent. This method has benefit that organic azides are generated in situ, thus making procedure more environmentally acceptable.

Nasir Baig et al. developed a highly efficient, acceptable and green method for azidealkyne-cycloaddition for the synthesis of triazoles (8) using a highly active magnetically recoverable nano ferrite-glutathione-copper (nano-FGT-Cu) catalyst in water under microwave irradiation conditions (Scheme 10). ${ }^{66}$ Easy magnetic separation of the catalyst removes the requirement for catalyst filtration after accomplishment of the reaction, which adds to the greenness of this reaction. The catalyst was characterized by XRD, TEM, and ICP-AES analysis.

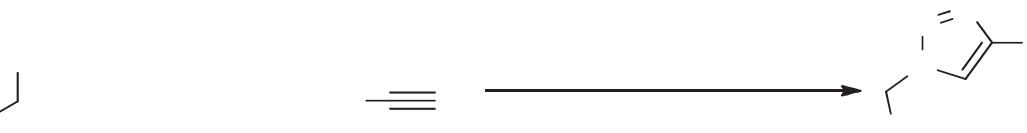

Scheme 10. Synthesis of 1,4-disubstituted 1,2,3-triazoles by one-pot multicomponent reaction catalyzed by magnetic nano-FGT-Cu catalyst.

1,4-Dihydroxyanthraquinone- $\mathrm{Cu}(\mathrm{II})$ nanoparticles immobilized on silica gel [AQ2$\mathrm{Cu}(\mathrm{II}) / \mathrm{APSiO}_{2}$ ] as extremely efficient, biodegradable heterogeneous nanocatalyst was developed by Shargi and co-workers. This nanocatalyst was used for click approach to the three-component synthesis of regioselective 1,2,3-triazole (10) products in water, from a number of epoxides, terminal alkynes and sodium azide (Scheme 11). ${ }^{69}$ The novel heterogeneous catalyst was prepared by simple impregnation of aminopropyl silica gel $\left(\mathrm{APSiO}_{2}\right)$ with [AQ2-Cu(II)]. The reaction was modest with a small reaction time in water. Further, isolation and handling of in situ generated organic azide intermediates that are potentially unstable, was avoided by this method. The most important benefit of using heterogenized [AQ2-Cu (II)/APSiO ${ }_{2}$ ] as catalyst in comparison with [AQ2-Cu(II)], is the easiness with which they can be recycled as stable species from the reaction mixture and reused. Study found that the catalytic activity of the present catalyst is intact even after ten cycles. It also showed that the increase in the activity of the 
heterogeneous catalyst was due to the nano-sized construction of catalyst and the uniform dispersion of metallic nanoparticles on high specific surface area of silica gel. The novel heterogeneous nanoparticles [AQ2-Cu(II)/APSiO ${ }_{2}$ ] was characterized using FTIR, XRD, AFM and SEM. Also, the active surface area of the $\mathrm{SiO}_{2}, \mathrm{APSiO}_{2}$ and $\left[\mathrm{AQ} 2-\mathrm{Cu}(\mathrm{II}) / \mathrm{APSiO}_{2}\right]$ was measured using a homemade TG analyzer.

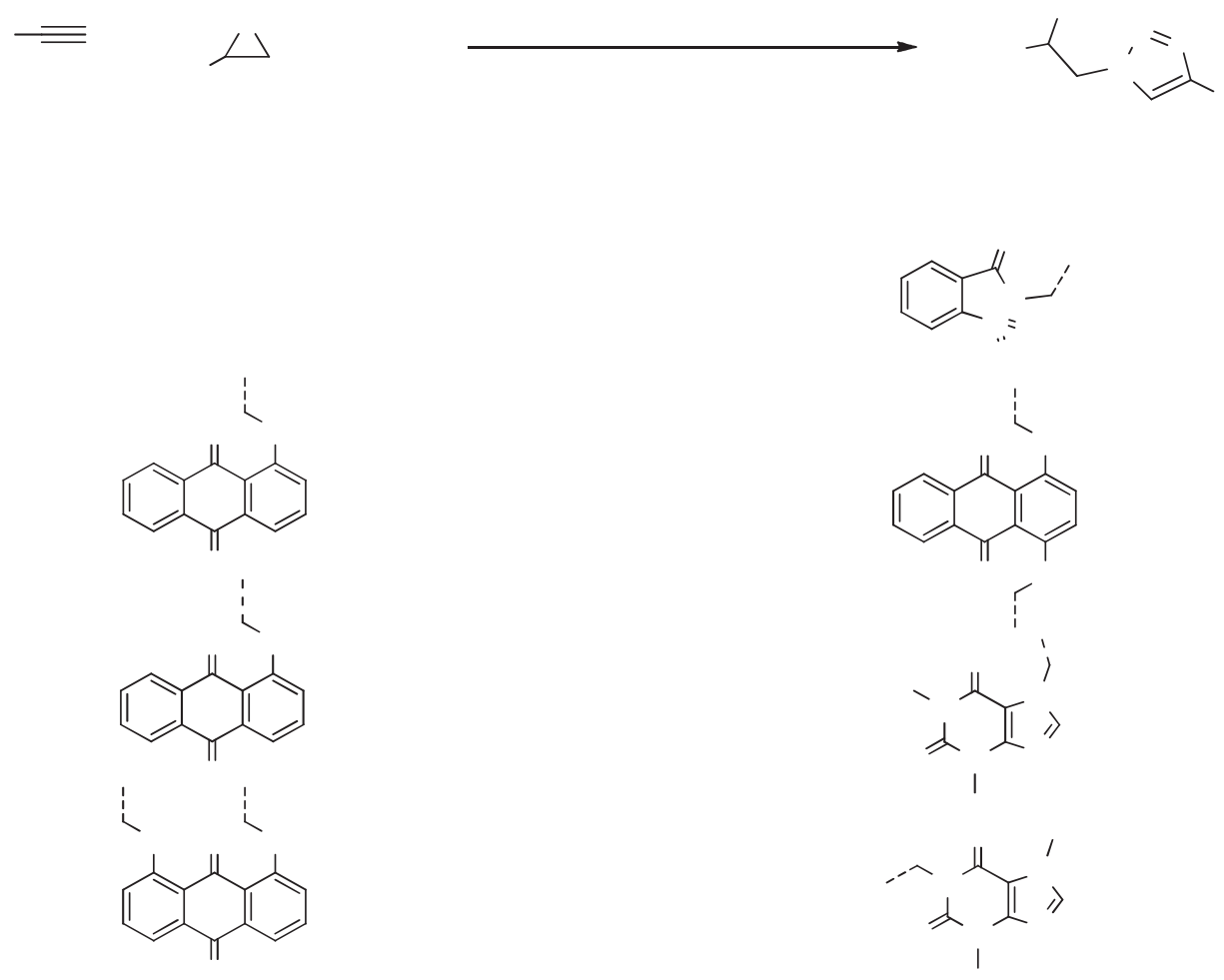

Scheme 11. 1,4-disubstituted 1,2,3-triazoles synthesis catalyzed by heterogeneous catalyst [AQ2-Cu(II)/APSiO 2 ].

Magnetically separable copper ferrite nanoparticles were developed as a catalyst for the synthesis of 1,2,3-triazoles (11) (Scheme 12). ${ }^{70}$ The reaction proceed via a three component reaction between various benzyl bromides, alkynes and sodium azide in water at $70{ }^{\circ} \mathrm{C}$. Further, the azide was produced in situ from the nucleophilic substitution reaction of organic halide with sodium azide. Moreover, the study found that the nanoparticles could be recovered and reused for several cycles with consistent activity. Because of the magnetic property, the catalyst was easily separated from the reaction mixture 


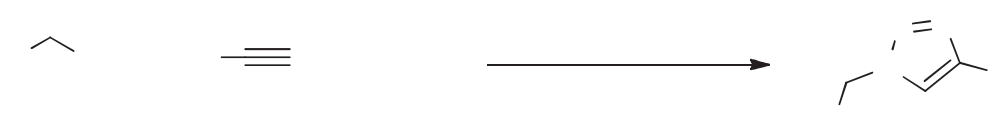

Scheme 12. Triazole synthesis in tap water using $\mathrm{CuFe}_{2} \mathrm{O}_{4}$ as catalyst.

Sharghi et al. reported a heterogeneous catalyst for the Huisgen 1,3-dipolar cycloaddition. The catalyst was prepared by immobilization of 4'-phenyl-2,2':6',2''-terpyridine copper(II) complex on activated multiwalled carbon nanotubes [AMWCNTs-OCuII-PhTPY] (Scheme 13). ${ }^{71}$ The recyclable catalyst was characterized by SEM, TEM, AFM, UV/vis and FT-IR techniques. The catalyst was recycled five times without any loss of catalytic activity.

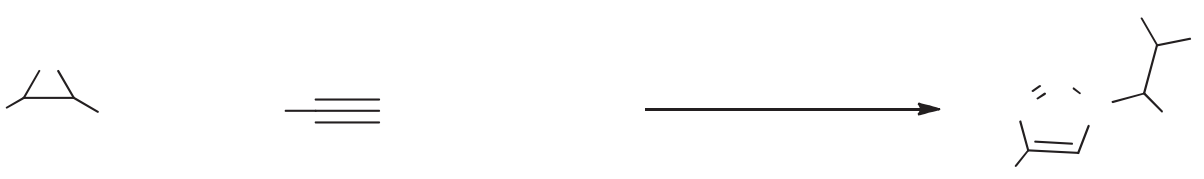

Scheme 13. Huisgen 1,3-dipolar cycloaddition catalyzed by AMWCNTs-OCuII-PhTPY.

In continuation of his work, Alonso et al. prepared copper nanoparticles on activated carbon and used as a heterogeneous catalyst for the multicomponent click synthesis of potentially biologically active triazoles (Scheme 14). A series of 1,4-disubstituted 1,2,3-triazoles (13) have been derived from the natural products (-)-menthol, lactic acid, D-glucose, oestrone, and cholesterol, and from the synthetic compound phenacetin, in a good yield. ${ }^{72}$ 


$$
\mathrm{R}^{1} \mathrm{X}+\mathrm{NaN}_{3}+\equiv \mathrm{R}^{2} \stackrel{\mathrm{CuNPs} / \mathrm{C}(0.5 \mathrm{~mol} \%)}{\mathrm{H}_{2} \mathrm{O}(2 \mathrm{~mL}), 70^{\circ} \mathrm{C}}
$$

13a: $\mathrm{R}^{1}=\mathrm{C}_{6} \mathrm{H}_{5} \mathrm{CH}_{2}^{-}, \mathrm{R}^{2}=\mathrm{C}_{\text {(1) }} \mathrm{X}=\mathrm{Br}, 77 \% \quad$ Time $=16 \mathrm{~h}$

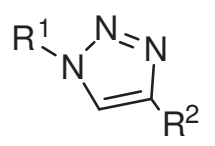

13

(6 examples, $70-95 \%)$

13b: $R^{1}=\mathrm{AcO}_{\mathrm{AcO}}^{\mathrm{OAc}}, \mathrm{R}^{2}=\mathrm{C}_{6} \mathrm{H}_{5}{ }^{-}, \mathrm{X}=\mathrm{Br}, 70 \%$ Time $=16 \mathrm{~h}$

13c: $\mathrm{R}^{1}=\mathrm{C}_{6} \mathrm{H}_{5} \mathrm{CH}_{2}{ }^{-}, \mathrm{R}^{2}=$

13d: $\mathrm{R}^{1}=\mathrm{C}_{6} \mathrm{H}_{5} \mathrm{CH}_{2}^{-}, \mathrm{R}^{2}=\mathrm{MeO}^{\mathrm{O}} \backslash \quad \mathrm{Br}, 95 \% \quad$ Time $=8 \mathrm{~h}$

13e: $\mathrm{R}^{1}=\mathrm{C}_{6} \mathrm{H}_{5} \mathrm{CH}_{2}{ }^{-}, \mathrm{R}^{2}=$<smiles>[Y]=CBr</smiles>

Scheme 14. Multicomponent synthesis of triazoles, catalyzed by copper nanoparticles on activated carbon.

Xiong and Cai attempted the synthesis of 1,4-disubstituted 1,2,3-triazoles (14) under microwave irradiation conditions in water using $\mathrm{Fe}_{3} \mathrm{O}_{4}$ supported $\mathrm{Cu}(\mathrm{I})$ magnetic nano particles as a heterogeneous catalyst (Scheme 15). ${ }^{73}$ The high activity, easy separation, commercial availability and reusability are the salient features of the catalyst. This catalyst reduces the reaction time; improve the purity as well as the yields of the products. No significant loss of catalyst activity was detected up to four cycles. 


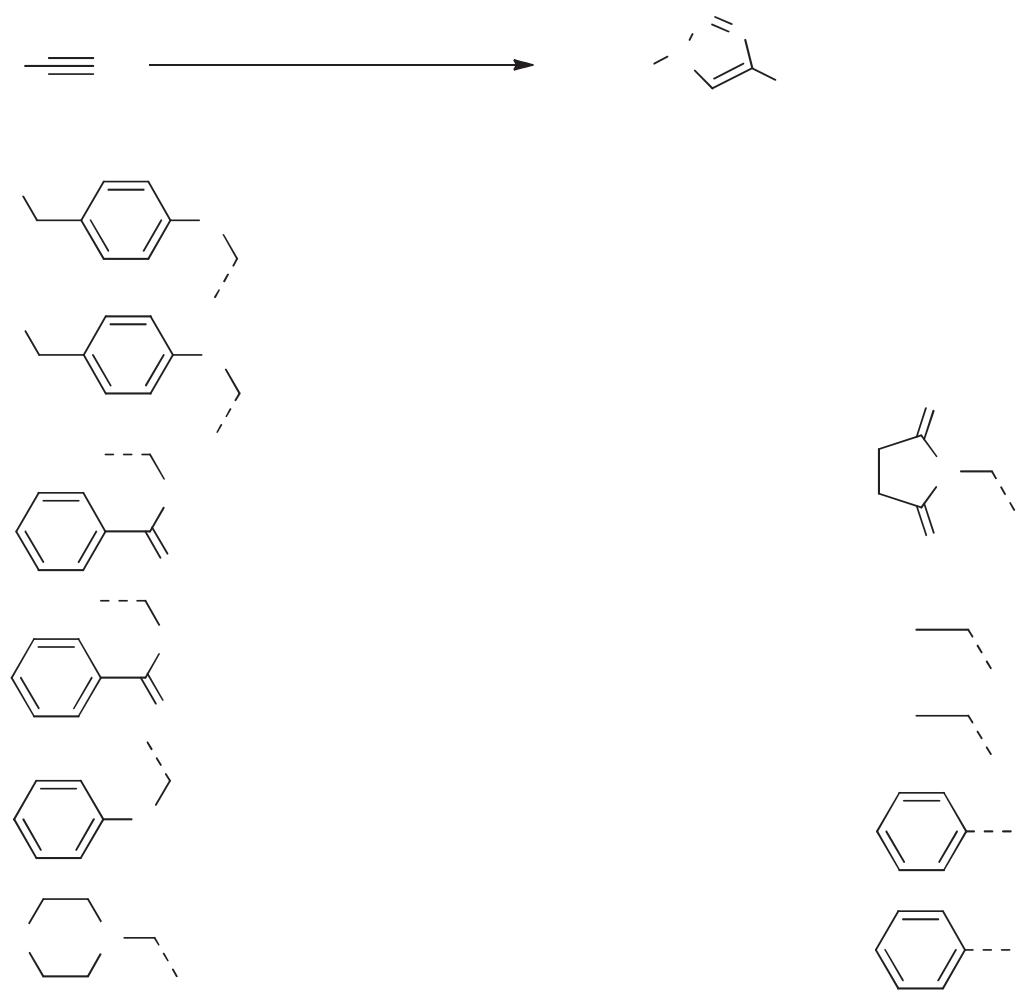

Scheme 15. The one pot and scale up click reaction under microwave-assisted conditions using $\mathrm{Fe}_{3} \mathrm{O}_{4}$ magnetic nanoparticle-supported $\mathrm{Cu}(\mathrm{I})$ catalyst.

Nador and co-workers presented copper nanoparticles supported on silica coated maghemite as a magnetically recoverable catalyst. The catalyst was used for multicomponent Huisgen 1,3-dipolar cycloaddition reaction between sodium azide, alkyl halide and terminal alkyne in water at $70{ }^{\circ} \mathrm{C}$ (Scheme 16). ${ }^{74}$ The CuNPs/MagSilica catalyst was characterized by means of TEM, EDX, XRD, TPR, and ICP-AES. The possibility of catalyst leaching in the reaction media was evaluated by using atomic absorption spectroscopy. The catalyst was used without any pretreatment.

$$
\mathrm{R}^{1} \mathrm{X}+\mathrm{R}^{2} \bar{\equiv}+\mathrm{NaN}_{3} \stackrel{\text { CuNPs/Mag Silica (4.3 mol \%) }}{\mathrm{H}_{2} \mathrm{O}(2 \mathrm{~mL}), 70^{\circ} \mathrm{C} \text {, air }} \mathrm{R}_{15}^{2}
$$

(10 examples, 87-96\%)
15a: $\mathrm{R}^{1}=\mathrm{C}_{6} \mathrm{H}_{5} \mathrm{CH}_{2^{-}}, \mathrm{R}^{2}=\mathrm{C}_{6} \mathrm{H}_{5^{-}}, \mathrm{X}=\mathrm{Br}, 98 \%$
15f: $\mathrm{R}^{1}=\mathrm{C}_{6} \mathrm{H}_{5} \mathrm{CH}_{2^{-}}, \mathrm{R}^{2}=\mathrm{C}_{6} \mathrm{H}_{5^{-}}, \mathrm{X}=\mathrm{Cl}, 83 \%$
15b: $\mathrm{R}^{1}=\mathrm{C}_{6} \mathrm{H}_{5} \mathrm{CH}_{2^{-}}, \mathrm{R}^{2}=4-\mathrm{BrC}_{6} \mathrm{H}_{4^{-}}, \mathrm{X}=\mathrm{Br}, 95 \%$
15g: $\mathrm{R}^{1}=4-\mathrm{CH}_{3} \mathrm{C}_{6} \mathrm{H}_{4} \mathrm{CH}_{2^{-}}, \mathrm{R}^{2}=\mathrm{C}_{6} \mathrm{H}_{5^{-}}, \mathrm{X}=\mathrm{Br}, 75 \%$
15c: $\mathrm{R}^{1}=\mathrm{C}_{6} \mathrm{H}_{5} \mathrm{CH}_{2^{-}}, \mathrm{R}^{2}=4-\left(\mathrm{CH}_{3}\right)_{2} \mathrm{NC}_{6} \mathrm{H}_{4^{-}}, \mathrm{X}=\mathrm{Br}, 98 \%$
15d: $\mathrm{R}^{1}=\mathrm{C}_{6} \mathrm{H}_{5} \mathrm{CH}_{2^{-}}, \mathrm{R}^{2}=\mathrm{n}-\mathrm{C}_{4} \mathrm{H}_{9^{-}}, \mathrm{X}=\mathrm{Br}, 93 \%$
15h: $\mathrm{R}^{1}=2-\mathrm{O}_{2} \mathrm{NC}_{6} \mathrm{H}_{4} \mathrm{CH}_{2^{-}}, \mathrm{R}^{2}=\mathrm{C}_{6} \mathrm{H}_{5^{-}}, \mathrm{X}=\mathrm{Br}, 77 \%$
15g: $\mathrm{R}^{1}=4-\mathrm{CH}_{2}=\mathrm{CHC}_{6} \mathrm{H}_{4^{-}}, \mathrm{R}^{2}=\mathrm{C}_{6} \mathrm{H}_{5^{-}}, \mathrm{X}=\mathrm{Cl}, 70 \%$
15e: $\mathrm{R}^{1}=\mathrm{C}_{6} \mathrm{H}_{5} \mathrm{CH}_{2^{-}}, \mathrm{R}^{2}=\mathrm{C}-\mathrm{C}_{6} \mathrm{H}_{11^{-}}, \mathrm{X}=\mathrm{Br}, 95 \%$
15g: $\mathrm{R}^{1}=4-\mathrm{CH}_{3} \mathrm{OC}_{6} \mathrm{H}_{4} \mathrm{CH}_{2^{-}}, \mathrm{R}^{2}=\mathrm{C}_{6} \mathrm{H}_{5^{-}}, \mathrm{X}=\mathrm{Cl}, 50 \%$

Scheme 16. Multicomponent Huisgen 1,3-dipolar cycloaddition reaction catalyzed by CuNPs/MagSilica catalyst. 
Gholinejad and Jeddi synthesized copper nanoparticles immobilized on agarose (CuNPs/agarose) as a heterogeneous catalyst (Scheme 17). ${ }^{75}$ The catalyst was used in the click synthesis of 1,4-disubstituted 1,2,3-triazoles (16) in green solvent water. The catalyst was described by EDX, SEM, TGA, TEM and XRD. The heterogeneous catalyst was used for five times with insignificant fall in catalytic activity.

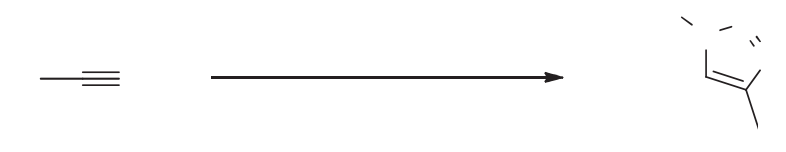

Scheme 17. Synthesis of 1, 4-disubstituted 1,2,3-triazoles using CuNPs/agarose catalyst.

Chavan and his group demonstrated for the first time cellulose supported cuprous iodide nanoparticles (cell-cuI NPs) as an highly efficient heterogeneous and recyclable catalyst in the click synthesis of 1,4-disubstituted 1,2,3-triazoles (17) by a one pot three component reaction between alkyl/aralkyl bromide, alkyne, and $\mathrm{NaN}_{3}$ in water (Scheme 18). ${ }^{76}$ The catalyst has been identified by XRD, HRTEM, SEM, ICP-AES, EDS and IR spectroscopy. The catalyst was found to be reusable for five consecutive runs without significant reduction in activity.

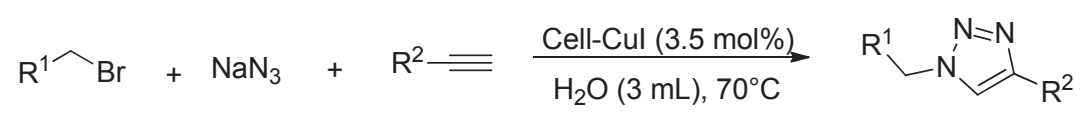

\section{7}

( 22 examples, $80-96 \%$ )

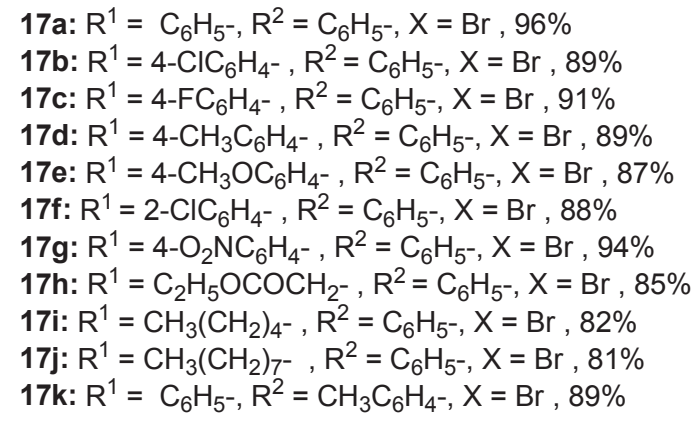

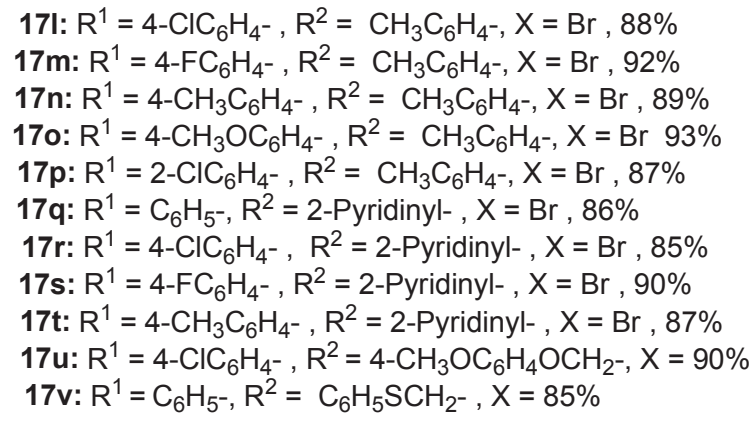

Scheme 18. Synthesis of 1,4-disubstituted-1,2,3-triazoles using cellulose supported cuprous iodide nanoparticles. 
Roy et al. reported the synthesis of a new $\mathrm{Cu}(\mathrm{II})$ attached functionalized SBA-15 type mesoporous silica and employed it as an efficient catalyst for the synthesis of 1,4-disubstituted 1,2,3-triazoles (18) through one pot click reaction between azides formed in situ from the corresponding amines and acetylenes in water at $0{ }^{\circ} \mathrm{C}$ to room temperature (Scheme 19). ${ }^{77}$ The mesoporous silica SBA-15 was first amine functionalized using 3-amino propyltriethoxysilane (3-APTES) which was then subjected to undergo Schiff base condensation reaction with 2pyridinecarboxaldehyde to form a new imine functionalized mesoporous SBA-15, followed by grafting of copper acetate onto it, to form Cu@PyIm-SBA-15 material. The catalyst was recycled for five cycles without any significant loss of catalytic activity. The catalyst was characterized by small-angle PXRD, TEM image analyses and EPR spectrum. The easy product purification and high recyclability of the catalyst make the procedure green and cost effective.

(1) Conc. $\mathrm{HCl}: \mathrm{H}_{2} \mathrm{O}(1: 1)$

$\mathrm{R}^{1} \mathrm{NH}_{2}$

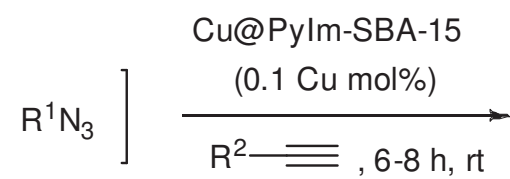

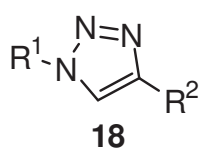

(14 examples $90-98 \%)$ 18a: $R^{1}=\mathrm{C}_{6} \mathrm{H}_{5^{-}}, \mathrm{R}^{2}=\mathrm{C}_{6} \mathrm{H}_{5^{-}}, 98 \%$
18b: $\mathrm{R}^{1}=4-\mathrm{O}_{2} \mathrm{NC}_{6} \mathrm{H}_{4^{-}}, \mathrm{R}^{2}=\mathrm{C}_{6} \mathrm{H}_{5^{-}}, 95 \%$
18c: $\mathrm{R}^{1}=2-\mathrm{IC}_{6} \mathrm{H}_{4^{-}}, \mathrm{R}^{2}=\mathrm{C}_{6} \mathrm{H}_{5^{-}}, 97 \%$
18d: $\mathrm{R}^{1}=4-\mathrm{CH}_{3} \mathrm{OC}_{6} \mathrm{H}_{4^{-}}, \mathrm{R}^{2}=\mathrm{C}_{6} \mathrm{H}_{5^{-}}, 95 \%$
18e: $\mathrm{R}^{1}=3-\mathrm{ClC}_{6} \mathrm{H}_{4^{-}}, \mathrm{R}^{2}=\mathrm{C}_{6} \mathrm{H}_{5^{-}}, 98 \%$
18f: $\mathrm{R}^{1}=3-\mathrm{ClCH}_{4^{-}}, \mathrm{R}^{2}=4-\mathrm{CNC}_{6} \mathrm{H}_{4^{-}}, 96 \%$
18g: $\mathrm{R}^{1}=2-\mathrm{O}_{2} \mathrm{NC}_{6} \mathrm{H}_{4^{-}}, \mathrm{R}^{2}=4-\mathrm{FC}_{6} \mathrm{H}_{4^{-}}, 94 \%$ 18h: $\mathrm{R}^{1}=3-\mathrm{ClCH}_{4^{-}}, \mathrm{R}^{2}=4-\mathrm{C}_{6} \mathrm{H}_{5} \mathrm{C}_{6} \mathrm{H}_{4^{-}}, 92 \%$

18i: $\mathrm{R}^{1}=2-\mathrm{O}_{2} \mathrm{NC}_{6} \mathrm{H}_{4^{-}}, \mathrm{R}^{2}=4-\mathrm{C}_{6} \mathrm{H}_{5} \mathrm{C}_{6} \mathrm{H}_{4^{-}}, 93 \%$

18j: $\mathrm{R}^{1}=2-\mathrm{O}_{2} \mathrm{NC}_{6} \mathrm{H}_{4^{-}}, \mathrm{R}^{2}=2-\mathrm{O}_{2} \mathrm{NC}_{6} \mathrm{H}_{4^{-}}, 96 \%-$

18k: $\mathrm{R}^{1}=2-\mathrm{O}_{2} \mathrm{NC}_{6} \mathrm{H}_{4^{-}}, \mathrm{R}^{2}=\mathrm{C}_{8} \mathrm{H}_{12^{-}}, 96 \%$

18I: $\mathrm{R}^{1}=\mathrm{C}_{6} \mathrm{H}_{5} \mathrm{CH}_{2-}, \mathrm{R}^{2}=2-$ Pyridinyl-, $92 \%$

18m: $\mathrm{R}^{1}=3-\mathrm{ClC}_{6} \mathrm{H}_{4^{-}}, \mathrm{R}^{2}=\mathrm{HOCH}_{2^{-}}, 90 \%$

18n: $\mathrm{R}^{1}=4-\mathrm{O}_{2} \mathrm{NC}_{6} \mathrm{H}_{4-}^{-}, \mathrm{R}^{2}=\mathrm{HOCH}_{2^{-}}, 96 \%$

Scheme 19. One pot click reaction catalyzed by $\mathrm{Cu} @$ Pylm-SBA-15 in water.

Hashemi and his co-workers reported for the first time in situ prepared copper nanoparticles on modified poly(styrene-co-maleic anhydride) (SMA) catalyst and employed it as an efficient catalyst for the one pot three component click synthesis of 1,4-disubstituted- $1 H$ 1,2,3-triazoles (19) from $\alpha$-haloketones or alkyle halides, sodium azide and terminal alkynes in water as a green reaction (Scheme 20). ${ }^{78}$ A new polymer supported copper iodide nanoparticle catalyst was prepared from the reaction of SMA with 4-aminopyridine to obtain the poly(styrene-co-maleimide) (SMI) and then the copper iodide nanoparticles were prepared in situ and immobilized on the polymer surface to give the supported catalyst. The catalyst allowed the regioselectivity of 1,4-disubstituted-1H-1,2,3-triazoles in good to excellent yields. The catalyst was recycled for five times with very low leaching of the supported catalyst. The catalyst was identified by SEM, energy dispersive spectroscopy analysis of X-rays and inductively coupled plasma. 


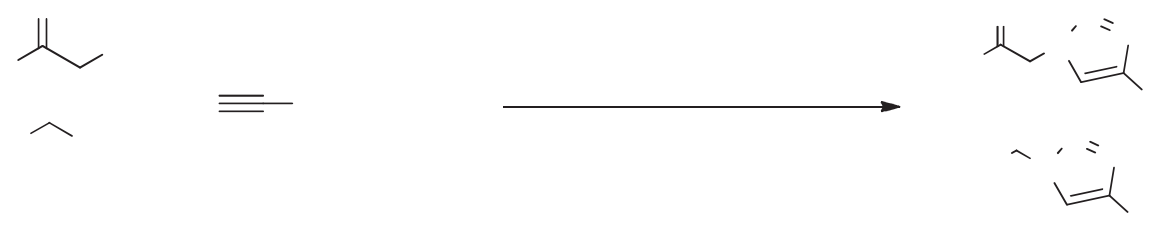

Scheme 20. Azide-alkyne click reaction catalyzed by $\mathrm{CuI}$ nanoparticles on modified poly(styrene-co-maleic anhydride) that is poly(styrene-co-maleimide) (SMI).

\subsection{Synthesis of 1,4-disubstituted 1,2,3-triazoles from preformed organic azides}

Pourjavadi et al. entrapped magnetic nanoparticles into the cross-linked poly(imidazole/imidazolium) immobilized $\mathrm{Cu}(\mathrm{II})$ and used it as an heterogeneous catalyst for the synthesis of 1,4-disubstituted 1,2,3-triazoles (20) via one-pot click reaction (Scheme 21). ${ }^{79}$ The catalyst was identified by SEM, TEM, TGA, XRD, EDAX, VSM, AAS, and FTIR technique. The catalyst was recovered without any loss of catalytic activity.

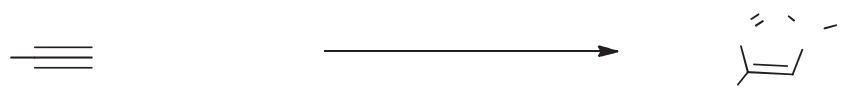

Scheme 21. One-pot click reaction catalyzed by MNP@PILCu.

Naeimi and Nejadshafiee demonstrated that $\mathrm{Cu}(\mathrm{I})$-modified $\mathrm{SiO}_{2}$, in particular $\mathrm{Cu}(\mathrm{I}) @$ phosphorated $\mathrm{SiO}_{2}$ (CPSi) catalyzed the click reaction for the synthesis of $\beta$-hydroxy1,2,3-triazoles from epoxides, terminal alkynes and sodium azide under green conditions (Scheme 22). ${ }^{80}$ The catalyst was reused ten times and no significant loss of activity was observed. The catalyst was fully characterized by FTIR, TGA, CHN, SEM, TEM, EDX and atomic adsorption spectroscopy. 


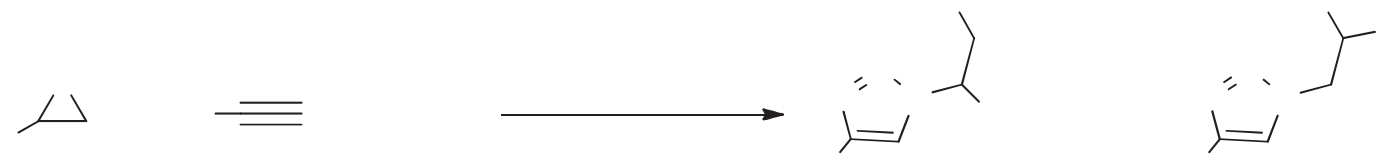

Scheme 22. Click reaction for the synthesis of b-hydroxy-1,2,3-triazoles catalyzed by CPSi catalyst.

A simple procedure for the rapid one-pot synthesis of 1,4-disubstituted 1,2,3-triazoles (22) in water using poly(ionic liquid)-coated magnetic nanoparticles $(\mathrm{P}[\mathrm{imCu} / \mathrm{IL}][\mathrm{Cl}])$ as a novel heterogeneous catalyst was described by Pourjavadi and his group (Scheme 23). ${ }^{81}$ The resulting magnetically separable nanoparticles as a catalyst has a high level of loading of copper ions without any aggregation and copper leaching. This property of the catalyst is especially useful in industrial applications. P[imCu/IL][Cl] was characterized using TEM, SEM, XRD, FT-IR, DTG and TGA analysis.

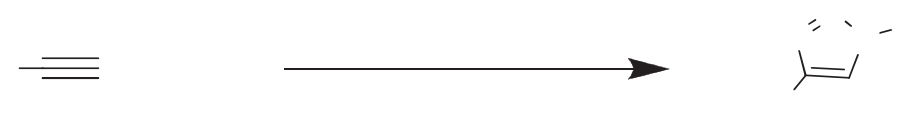

Scheme 23. Synthesis of 1,4-disubstituted 1,2,3-triazoles catalyzed by P[imCu/IL][Cl].

Recently, a copper nano catalyst supported on modified silica mesopore KIT-5 was prepared by Mirsafaei and his group. The 3-aminopropyltriethoxysilane (APTES) on KIT-5 was synchronized with $\mathrm{Cu}(\mathrm{I})$. SEM, FT-IR, XRD and EDAXS techniques were used to characterize the obtained catalyst. The novel catalyst was found highly active and used in the synthesis 1,4- 
disubstituted 1,2,3-triazoles (23) via click reaction between terminal alkynes, $\alpha$-halo ketones or alkyl halide or sodium azide in water as a green solvent (Scheme 24$).^{82}$
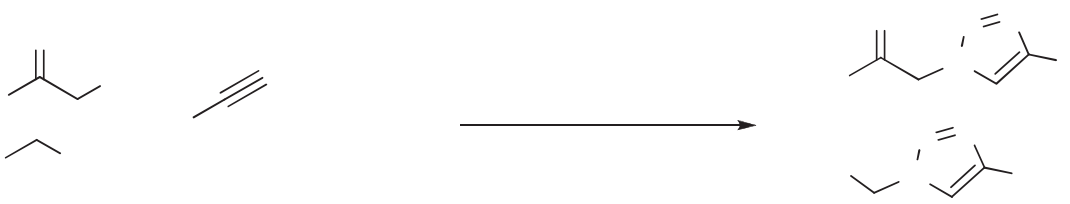

Scheme 24. Click reaction in water using copper nanoparticles on modified KIT-5 as catalyst.

In 2015, Saadat and co-workers synthesized $\mathrm{Cu}(\mathrm{I})$ iodide nanoparticles on polyaniline (PANI@CuI-NPs) as a heterogeneous catalyst for the synthesis of 1,4-disubstituted 1,2,3triazoles (24) from multicomponent click reaction between $\alpha$-halo ketones/benzyl halide, terminal alkyne and sodium azide (Scheme 25). ${ }^{83}$ The catalyst was used for five cycles with high catalytic activity.

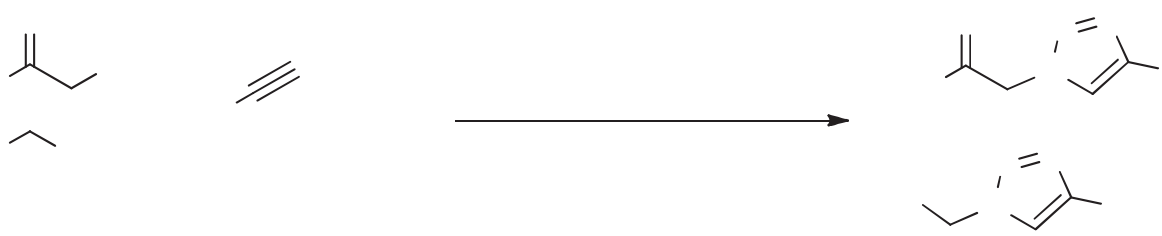

Scheme 25. 1,3-dipolar Huisgen cycloaddition reaction of $\alpha$-halo ketones/benzyl halide, terminal alkyne and sodium azide.

A highly loaded heterogeneous polymeric copper catalyst was synthesized by the immobilization of copper ions in a graphene oxide/poly(vinyl imidazole) nanocomposite and employed for the one-pot three component click synthesis of triazoles (25) (Scheme 26). ${ }^{84}$ The reaction was carried out in water using only $0.1 \%$ of catalyst. The reaction also proceeded well 
with only 0.002 mol\% of catalyst showing high catalytic activity of catalyst. The catalyst was reused for five cycles without any leaching of the supported catalyst.

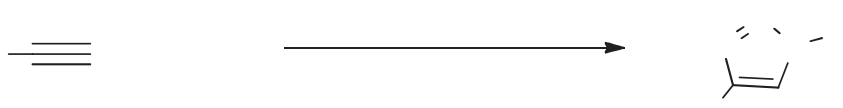

Scheme 26. Click synthesis of triazoles using polymeric copper catalyst.

In 2015, Lua and co-workers prepared a new magnetic $\mathrm{NiFe}_{2} \mathrm{O}_{4}$ supported glutamate-copper catalyst by a straightforward method. It was found to be an excellent catalyst for one-pot synthesis of 1,4-disubstituted-1,2,3-triazoles (26) in water at room temperature (Scheme 27). ${ }^{85}$ This protocol has many advantages like aqueous reaction medium, ambient reaction condition, high yields, wide substrate scope, easy separation of catalyst using an external magnet and efficient recycling. The catalyst was characterized by XRD, EDX, TEM, SEM, XPS and VSM.

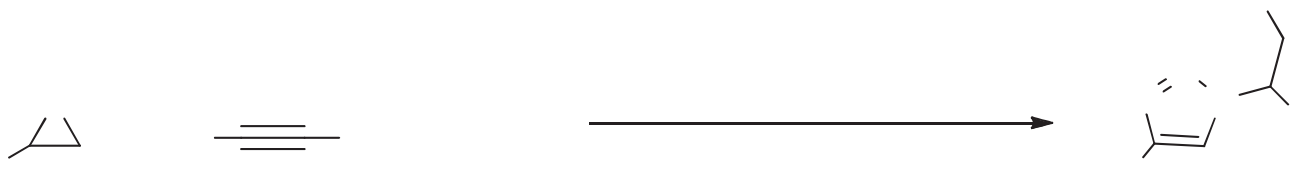

Scheme 27. $\mathrm{NiFe}_{2} \mathrm{O}_{4}$ catalyst for one-pot synthesis of 1,4-disubstituted-1,2,3-triazoles.

Magnetic copper nanoparticles were prepared by the immobilization of copper sulphate onto multi-layered poly(2-dimethylaminoethyl acrylamide)-coated $\mathrm{Fe}_{3} \mathrm{O}_{4}$ nanoparticles. The catalytic 
activity of the catalyst was found to be very high for the click synthesis of 1,2,3-triazoles (27) (Scheme 28). ${ }^{86}$ Only a $0.3 \mathrm{~mol} \%$ of catalyst was found to be sufficient to complete the reaction in water at $50{ }^{\circ} \mathrm{C}$. The prepared catalyst was highly stable and efficient. The catalyst was characterized by various techniques.

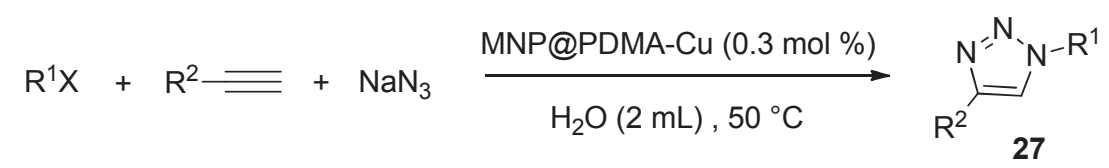

(15 examples, 87-96\%)
27a: $\mathrm{R}^{1}=\mathrm{C}_{6} \mathrm{H}_{5} \mathrm{CH}_{2^{-}}, \mathrm{R}^{2}=\mathrm{C}_{6} \mathrm{H}_{5^{-}}, \mathrm{X}=\mathrm{Br}, 96 \%$
27i: $\mathrm{R}^{1}=\mathrm{CH}_{3} \mathrm{CH}_{2} \mathrm{CH}_{2^{-}}, \mathrm{R}^{2}=\mathrm{C}_{6} \mathrm{H}_{5^{-}}, \mathrm{X}=\mathrm{Br}, 88 \%$
27b: $\mathrm{R}^{1}=4-\mathrm{CH}_{3} \mathrm{C}_{6} \mathrm{H}_{4} \mathrm{CH}_{2^{-}}, \mathrm{R}^{2}=\mathrm{C}_{6} \mathrm{H}_{5^{-}}, \mathrm{X}=\mathrm{Br}, 91 \%$
27c: $\mathrm{R}^{1}=4-\mathrm{ClC}_{6} \mathrm{H}_{4} \mathrm{CH}_{2^{-}}, \mathrm{R}^{2}=\mathrm{C}_{6} \mathrm{H}_{5^{-}}, \mathrm{X}=\mathrm{Br}, 95 \%$
27j: $\mathrm{R}^{1}=\mathrm{H}_{2} \mathrm{NCOCH}_{2^{-}}, \mathrm{R}^{2}=\mathrm{C}_{6} \mathrm{H}_{5^{-}}, \mathrm{X}=\mathrm{Br}, 84 \%$
27d: $\mathrm{R}^{1}=4-\mathrm{O}_{2} \mathrm{NC}_{6} \mathrm{H}_{4} \mathrm{CH}_{2^{-}}, \mathrm{R}^{2}=\mathrm{C}_{6} \mathrm{H}_{5^{-}}, \mathrm{X}=\mathrm{Br}, 97 \%$
27k: $\mathrm{R}^{1}=\mathrm{C}_{6} \mathrm{H}_{5} \mathrm{CH}_{2^{-}}, \mathrm{R}^{2}=\mathrm{CH}_{3}\left(\mathrm{CH}_{2}\right)_{3} \mathrm{CH}_{2^{-}}, \mathrm{X}=\mathrm{Br}, 92 \%$
27e: $\mathrm{R}^{1}=4-\mathrm{BrC}_{6} \mathrm{H}_{4} \mathrm{CH}_{2^{-}}, \mathrm{R}^{2}=\mathrm{C}_{6} \mathrm{H}_{5^{-}}, \mathrm{X}=\mathrm{Br}, 90 \%$ 27m: $\mathrm{R}^{1}=\mathrm{CH}_{3}\left(\mathrm{CH}_{2}\right)_{5} \mathrm{CH}_{2^{-}}, \mathrm{R}^{2}=\mathrm{CH}_{3}\left(\mathrm{CH}_{2}\right)_{3} \mathrm{CH}_{2^{-}}, \mathrm{X}=\mathrm{Br}, 77 \%$
27f: $\mathrm{R}^{1}=\mathrm{C}_{6} \mathrm{H}_{5} \mathrm{CH}_{2^{-}}, \mathrm{R}^{2}=\mathrm{C}_{6} \mathrm{H}_{5^{-}}, \mathrm{X}=\mathrm{OTs}, 94 \%$
26n: $\mathrm{R}^{1}=\mathrm{C}_{6} \mathrm{H}_{5} \mathrm{COCH}_{2^{-}}, \mathrm{R}^{2}=\mathrm{CH}_{3}\left(\mathrm{CH}_{2}\right)_{3} \mathrm{CH}_{2^{-}}, \mathrm{X}=\mathrm{Br}, 82 \%$
27g: $\mathrm{R}^{1}=\mathrm{C}_{6} \mathrm{H}_{5} \mathrm{COCH}_{2^{-}}, \mathrm{R}^{2}=\mathrm{C}_{6} \mathrm{H}_{5^{-}}, \mathrm{X}=\mathrm{Br}, 87 \%$
27h: $\mathrm{R}^{1}=\mathrm{C}_{2} \mathrm{H}_{5} \mathrm{OCOCH}_{2^{-}}, \mathrm{R}^{2}=\mathrm{C}_{6} \mathrm{H}_{5^{-}}, \mathrm{X}=\mathrm{Br}, 85 \%$
26o: $\mathrm{R}^{1}=\mathrm{CH}_{3}\left(\mathrm{CH}_{2}\right)_{5} \mathrm{CH}_{2^{-}}, \mathrm{R}^{2}=\mathrm{CH}_{3}\left(\mathrm{CH}_{2}\right)_{3} \mathrm{CH}_{2^{-}}, \mathrm{X}=\mathrm{Cl}, 75 \%$

Scheme 28. Click synthesis of 1,2,3-triazoles using magnetic copper nanoparticles.

In 2016, Bhardwaj and co-workers developed copper nanoparticles onto ethylene diamine functionalized with inorganic/organic magnetic composite $\mathrm{Cu}(0)-\mathrm{Fe}_{3} \mathrm{O}_{4} @ \mathrm{SiO}_{2} / \mathrm{NH}_{2}$ cel and the catalytic activity of the catalyst was studied in the one-pot synthesis of 1,4-disubstituted 1,2,3triazoles (28) (Scheme 29). ${ }^{87}$ Functionalization of inorganic/organic composite by ethylene diamine allows the creation of active sites for the immobilization of $\mathrm{Cu}(0)$ nanoparticles. The catalyst was recognized by various techniques like FTIR, TGA, XRD, SEM, HRTEM, EDX, ICP-AES, UV-Vis and VSM.

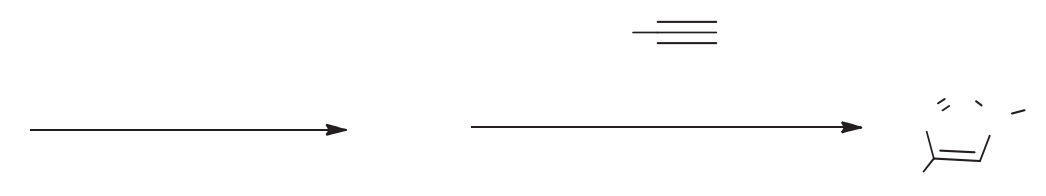

Scheme 29. Synthesis of 1,4-disubstituted 1,2,3-triazoles via $\mathrm{Cu}(0)-\mathrm{Fe}_{3} \mathrm{O}_{4} @ \mathrm{SiO}_{2} / \mathrm{NH}_{2}$ cel catalyst. 
Hydrazine hydrate as reducing agent was used to prepare PVP stabilized copper nanoparticles in ionic liquid (Scheme 30). ${ }^{88}$ These nanoparticles were used as catalyst for the 1,3dipolar cycloaddition reaction between alkyne and aryl azide to yield 1,2,3-triazoles (29) in high yields. The nanoparticles were characterized by SEM, TEM, and EDAX. Further, it was also observed that the recycling of the catalyst does not involve segregation of the particles from the solvent. The catalytic system worked extremely well for five consecutive runs after separation of the product. Thus the particles can be recycled for a number of times.

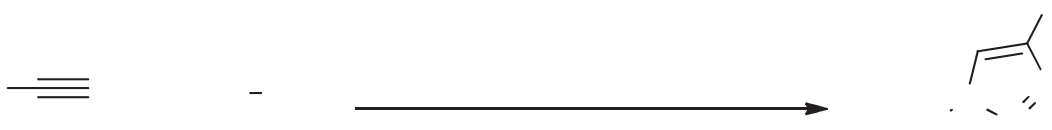

Scheme 30. PVP stabilized copper nanoparticles catalyzed synthesis of triazoles.

Zhang et al. prepared a novel polyvinylpyrrolidone(PVP) coated $\mathrm{Cu}(1)$ oxide nanoparticles [PVP-coated $\mathrm{Cu}_{2} \mathrm{O}-\mathrm{NPs}$ ] and applied these nanoparticles as the catalyst for the azide-alkyne click chemistry for the synthesis of 1,2,3-triazoles (30) in water under aerobic conditions (Scheme 31). ${ }^{89}$ TEM was used to characterize the $\mathrm{Cu}_{2} \mathrm{O}$-NPs which shows that the nanoparticles were well dispersed in aqueous solution and have a size of $20 \pm 10 \mathrm{~nm}$ and form small aggregates. PVP was chosen as a stabilizing and dispersing agent to make a stable $\mathrm{Cu}_{2} \mathrm{O}-\mathrm{NPs}$ catalyst. The size of these small aggregates was determined by DLC. The $\mathrm{Cu}_{2} \mathrm{O}$ composition of the $\mathrm{Cu}_{2} \mathrm{O}-\mathrm{NPs}$ was obtained by ICP analysis implies that the nanoparticles are coated with PVP, making the whole composite stable in aqueous solution. The XRD method proves that the nanoparticles are $\mathrm{Cu}_{2} \mathrm{O}-$ NP. XPS indicates that $\mathrm{CuO}$ is present only on the surface of the $\mathrm{Cu}_{2} \mathrm{O}-\mathrm{NPs}$ as a thin amorphous outer shell. The cytotoxicity of $\mathrm{Cu}_{2} \mathrm{O}-\mathrm{NP}$ was evaluated by an in vitro 3-(4,5-dimethylthiazol-2yl)-2,5-diphenyltetrazolium bromide (MTT) assay. The catalytic activity of the catalyst was investigated in the Huisgen cycloaddition reaction using 6-azidohexane-1-ol and hex-5-yn-1-ol as model substrates in water and aerobic conditions. The PVP coated $\mathrm{Cu}_{2} \mathrm{O}-\mathrm{NPs}$ is more efficient in azide-alkyne click reactions in water for both aliphatic and aromatic azides and alkynes and less toxic than the normally used $\mathrm{CuSO}_{4} /$ reductant catalyst systems. 


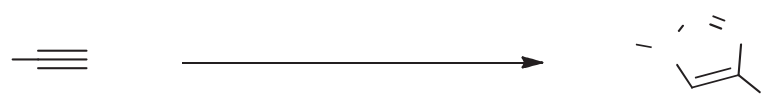

Scheme 31. Click reaction catalyzed by $\mathrm{Cu}_{2} \mathrm{O}-\mathrm{NPs}$.

Fernandez et al. established a non-magnetic and magnetic supported $\mathrm{Cu}(\mathrm{I})$ chelating adsorbents (Si-BPMA.Cu+, Dw-BPMA.Cu+, Si-BPA.Cu+ and $\mathrm{Fe}_{3} \mathrm{O}_{4} @ \mathrm{Si}-\mathrm{BPA} \cdot \mathrm{Cu}$ ) as highly effective heterogeneous catalyst for click chemistry (Scheme 32). ${ }^{90}$ These adsorbents were organized from silica or silica-coated magnetite nanoparticles by the incorporation of the chelating ligands through a number of efficient ways based on the aza-Michael-type addition of vinyl sulfone to amines. The copper complexation capabilities of these materials permit them to play as a heterogeneous click catalytic systems when used in their complexed form. The innovative non-magnetic and magnetic $\mathrm{Cu}(\mathrm{I})$-supported hybrid resources proved to be robust and efficient heterogeneous catalysts that are capable to support click reactions by using particularly low amounts with insignificant copper leaching, mainly in case of the silica-based non-magnetic adsorbents, rapid and easy removal by filtration or magnetic decantation together with recyclability properties. This excellent catalytic profile is due to the stabilization of $\mathrm{Cu}(\mathrm{I})$ mediated by its complexation. These materials open new opportunities for the preparation of greener clicked compound (31).

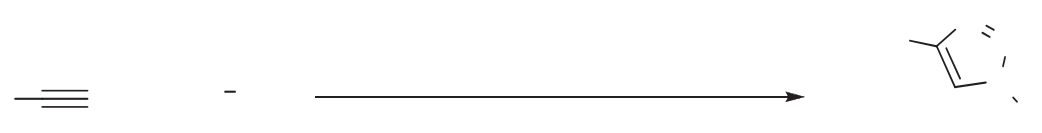

Scheme 32. Click reaction using nonmagnetic Si-PMA·Cu+NPs (A), Si-His·Cu+NPs (B), BPMA $\cdot \mathrm{Cu}+\mathrm{NPs}(\mathrm{C}), \mathrm{Dw}-\mathrm{BPMA} \cdot \mathrm{Cu}+\mathrm{NPs}(\mathrm{D}), \mathrm{Si}-\mathrm{BPA} \cdot \mathrm{Cu}+\mathrm{NPs}(\mathrm{E})$ and magnetic nanoparticles Fe3O4@Si-BPA.Cu (F) as heterogeneous catalyst. 
$\mathrm{Cu}(0)$-nanoparticles in the nano pores of modified montmorillonite were developed (Scheme 33). ${ }^{91}$ The specific surface area, pore diameter and pore size distribution of montmorillonite were adjusted by controlled acid activation. The study found that the pores provided the space for nanoparticle formation and limited the growth of the particles up to the preferred nano size range. The TEM image of nanoparticles showed that dispersed $\mathrm{Cu}(0)$ nanoparticles were formed in the micro- and mesopores of activated montmorillonite. From the TEM study, it was also observed that the nanoparticles were spherical, well separated from each other and having sizes below $10 \mathrm{~nm}$. The powder XRD analysis confirmed construction of $\mathrm{Cu}(0)$-nanoparticles. The high surface area modified montmorillonite as support for $\mathrm{Cu}(0)$ nanoparticles revealed a beneficial effect on the rate and regioselectivity of 1,4-disubstituted 1,2,3-triazoles (32). The nano catalysts were reprocessed for a lot of reactions without significant reduction of catalytic activity under the same conditions.

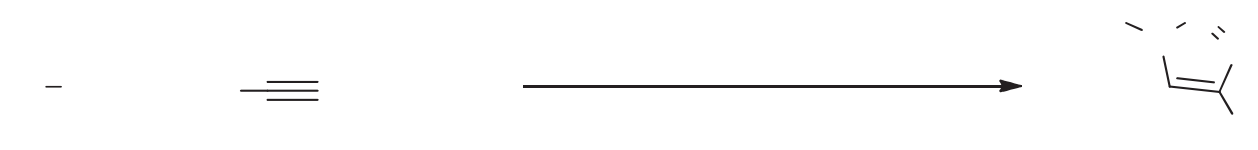

Scheme 33. Azide alkyne click reaction in water catalyzed by $\mathrm{Cu}(0)$ nanoparticles.

Bimetallic copper nanoparticles as a simple heterogeneous catalyst to synthesize 1,4disubstituted 1,2,3-triazoles (33) in water were presented by Hudson et al. (Scheme 34). ${ }^{92}$ Interestingly, in this system, the $\mathrm{Fe}(0)$ core play three-fold role. First, it provides a means for magnetic recoverability, second, it helps as a source of electrons to reduce $\mathrm{Cu}$ (II) into $\mathrm{Cu}$ (I) and third, it acts as a support for $\mathrm{Cu}(\mathrm{I})$ species to avoid their liberation as soluble ions, permitting a heterogeneous mechanism. The synthesis of $\mathrm{Cu} @$ FeNPs catalyst proceeds without the use of any ligand, making this reaction economical. This work represents two general green chemistry themes: magnetic nanoparticles as easily recoverable catalysts and aqueous "click chemistry". 

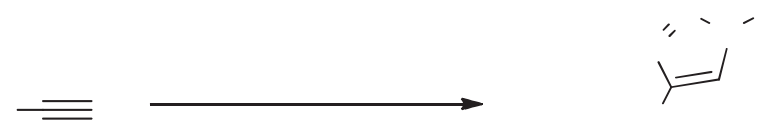

Scheme 34. Azide-alkyne click reaction catalyzed by magnetic copper-iron nanoparticles $\mathrm{Cu} @ \mathrm{Fe}$ NPs.

Kumar et al. presented the synthesis of aminoclay supported copper nanoparticles for the azide-alkyne click chemistry in water under aerobic conditions (Scheme 35). ${ }^{93}$ The catalyst permitted the regioselectivity of 1,4-disubstituted 1,2,3-triazoles (34) in good to excellent yields. The study found that no distinct difference in yield and reaction rate was detected when the recovered catalyst was used. The catalyst was recycled for five times with very low leaching of the supported catalyst. The efficient binding of $\mathrm{Cu}$ nanoparticles over aminoclay support avoids the accumulation of $\mathrm{Cu}$ nanoparticles and clarified the longer lifetime of the catalyst $(\mathrm{Cu} /$ aminoclay nanocomposite) in the triazole production.

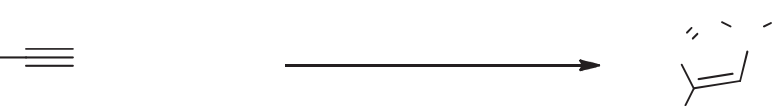

Scheme 35. Synthesis of triazoles catalyzed by copper nanoparticles immobilized on aminoclay.

Chitosan-copper (chit-CuSO${ }_{4}$ ) catalyst was synthesized via immobilization of copper sulphate on chitosan by stirring an aqueous suspension of chitosan in water with copper sulfate (Scheme 36). ${ }^{94}$ The catalyst thus formed has been utilized for the azide-alkyne cycloaddition reactions in water at ambient temperature yielding 1,4-disubstituted 1,2,3-triazoles (35) in good yield. The catalyst can be recycled and reused for five consecutive runs without any loss of activity. The catalyst was characterized by XRD and SEM. 

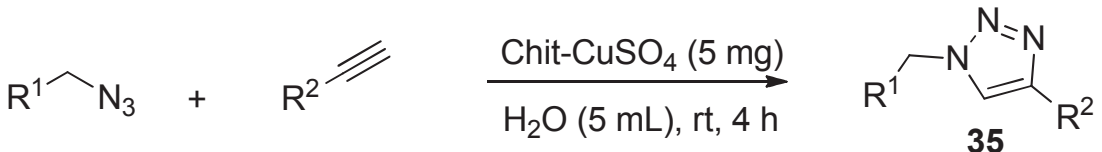

( 19 examples, $12-99 \%$ )
35a: $\mathrm{R}^{1}=\mathrm{C}_{6} \mathrm{H}_{5^{-}}, \mathrm{R}^{2}=\mathrm{C}_{6} \mathrm{H}_{5^{-}}, 99 \%$
35b: $\mathrm{R}^{1}=\mathrm{C}_{6} \mathrm{H}_{5^{-}}, \mathrm{R}^{2}=4-\mathrm{CH}_{3} \mathrm{C}_{6} \mathrm{H}_{4^{-}}, 99 \%$
35c: $\mathrm{R}^{1}=\mathrm{C}_{6} \mathrm{H}_{5^{-}}, \mathrm{R}^{2}=4-\mathrm{CH}_{3} \mathrm{OC}_{6} \mathrm{H}_{4^{-}}, 99 \%$
35d: $R^{1}=\mathrm{C}_{6} \mathrm{H}_{5^{-}}, \mathrm{R}^{2}=4-\mathrm{ClC}_{6} \mathrm{H}_{4}, 98 \%$
35e: $\mathrm{R}^{1}=\mathrm{C}_{6} \mathrm{H}_{5}, \mathrm{R}^{2}=4-\mathrm{CH}_{3} \mathrm{OC}_{6} \mathrm{H}_{5^{-}}, 97 \%$
35f: $\mathrm{R}^{1}=\mathrm{C}_{6} \mathrm{H}_{5^{-}} \mathrm{R}^{2}=4-\mathrm{NO}_{2} \mathrm{C}_{6} \mathrm{H}_{5^{-}}, 95 \%$
35g: $\mathrm{R}^{1}=\mathrm{C}_{6} \mathrm{H}_{5^{-}}, \mathrm{R}^{2}=$ 2-Pyridinyl- , 96\%
35h: $\mathrm{R}^{1}=3-\mathrm{O}_{2} \mathrm{NC}_{6} \mathrm{H}_{4^{-}}, \mathrm{R}^{2}=\mathrm{C}_{6} \mathrm{H}_{5^{-}}, 94 \%$
35i: $\mathrm{R}^{1}=4-\mathrm{O}_{2} \mathrm{NC}_{6} \mathrm{H}_{4^{-}}, \mathrm{R}^{2}=\mathrm{C}_{6} \mathrm{H}_{5^{-}}, 96 \%$
35j: $\mathrm{R}^{1}=\mathrm{C}_{6} \mathrm{H}_{5^{-}}, \mathrm{R}^{2}=\mathrm{CH}_{3}\left(\mathrm{CH}_{2}\right)_{3^{-}}, 12 \%$

35k: $\mathrm{R}^{1}=4-\mathrm{O}_{2} \mathrm{NC}_{6} \mathrm{H}_{4^{-}}, \mathrm{R}^{2}=\mathrm{C}_{6} \mathrm{H}_{5^{-}}, 96 \%$

35I: $\mathrm{R}^{1}=4-\mathrm{FC}_{6} \mathrm{H}_{4^{-}}, \mathrm{R}^{2}=\mathrm{C}_{6} \mathrm{H}_{5^{-}}, 97 \%$

35m: $\mathrm{R}^{1}=3-\mathrm{O}_{2} \mathrm{NC}_{6} \mathrm{H}_{4^{-}}, \mathrm{R}^{2}=4-\mathrm{CH}_{3} \mathrm{C}_{6} \mathrm{H}_{4^{-}}, 94 \%$

35n: $\mathrm{R}^{1}=4-\mathrm{O}_{2} \mathrm{NC}_{6} \mathrm{H}_{4^{-}}, \mathrm{R}^{2}=4-\mathrm{CH}_{3} \mathrm{C}_{6} \mathrm{H}_{4^{-}}, 96 \%$

35o: $\mathrm{R}^{1}=4-\mathrm{FC}_{6} \mathrm{H}_{4^{-}}, \mathrm{R}^{2}=4-\mathrm{CH}_{3} \mathrm{C}_{6} \mathrm{H}_{4^{-}}, 98 \%$

35p: $\mathrm{R}^{1}=4-\mathrm{O}_{2} \mathrm{NC}_{6} \mathrm{H}_{4^{-}}, \mathrm{R}^{2}=4-\mathrm{CH}_{3} \mathrm{OC}_{6} \mathrm{H}_{4^{-}}, 96 \%$

35p: $\mathrm{R}^{1}=4-\mathrm{FC}_{6} \mathrm{H}_{4^{-}}, \mathrm{R}^{2}=4-\mathrm{CH}_{3} \mathrm{OC}_{6} \mathrm{H}_{4^{-}}, 98 \%$

35q: $\mathrm{R}^{1}=3-\mathrm{O}_{2} \mathrm{NC}_{6} \mathrm{H}_{4^{-}}, \mathrm{R}^{2}=4-\mathrm{CH}_{3} \mathrm{OC}_{6} \mathrm{H}_{4^{-}}, 96 \%$

35r: $\mathrm{R}^{1}=\mathrm{CH}_{2} \mathrm{CHCH}_{2^{-}}, \mathrm{R}^{2}=\mathrm{C}_{6} \mathrm{H}_{5^{-}}, 93 \%$

Scheme 36. Click reaction using the chit- $\mathrm{CuSO}_{4}$ catalyst.

Ali and his group investigated a novel heterogeneous ligand-accelerated copper loaded catalyst (DHQD)2PHAL. The catalyst is very simple to handle and is environmentally secure. (DHQD)2PHAL catalyzes the three-component reaction for the construction of 1,4-disubstituted 1,2,3-triazoles (36) from alkyl halide, sodium azide and alkyne (Scheme 37). ${ }^{95}$ Furthermore, the catalyst can be recycled and reused several times without any significant loss in activity. The catalyst was easily arranged in large scale quantity with high loading level of copper ion.

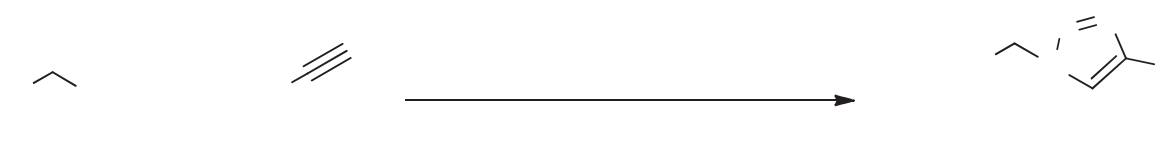

Scheme 37. Experiment for synthesis of 1,2,3-triazole catalyzed by ligand-accelerated copper loaded catalyst (DHQD)2PHAL from variety of organic azides and alkynes in water at room temperature.

In 2015, Hajlaoui and his group developed a modest and very efficient synthetic protocol for the synthesis of 1,4-disubstituted 1,2,3-triazoles (37) from copper nano particles cycloaddition of terminal acetylene with carbohydrate azide using green solvent water (Scheme 38). ${ }^{96}$ The experimental results showed that the reaction was influenced by steric effects, whereas in the presence of carbohydrate group shows complete regioselectivity. The CuNPs not only provide suitable yields but also gives products under very mild conditions. This method could offer good opportunities for the formation of important heterocyclic compounds. 


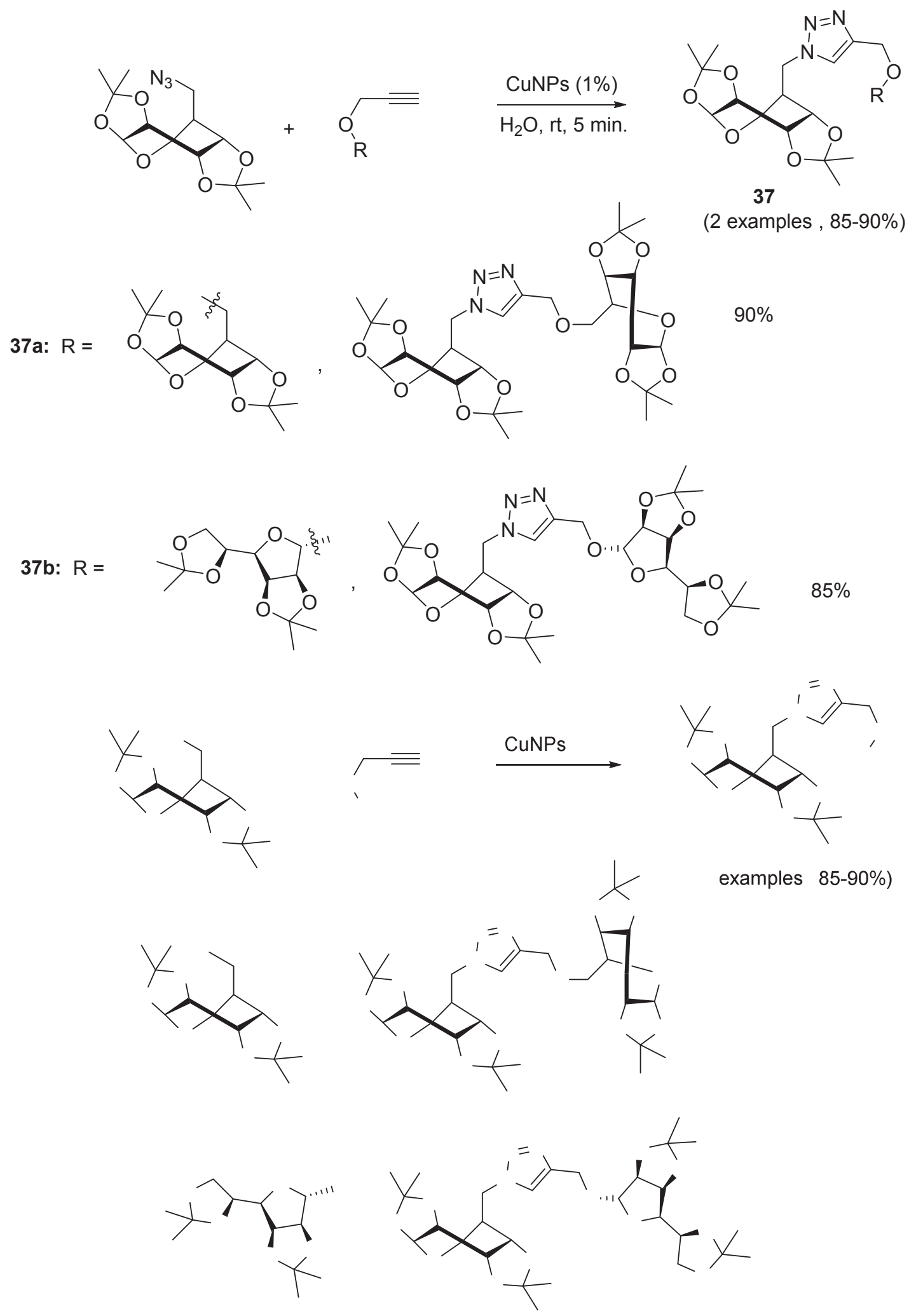

Scheme 38. Copper nanoparticle-catalyzed reactions of terminal acetylenes with carbohydrate azides. 
Zhang and co-workers synthesized a novel catalyst by the combination of $\mathrm{CMP}$ and $\mathrm{Cu}_{2} \mathrm{O}$. The acidic CMP catalyst was found to be a highly competent heterogeneous catalyst for the synthesis of 1,4-disubstituted 1,2,3-triazoles (38) through a suitable 1,3-dipolar cycloaddition (Scheme 39). ${ }^{97}$ The catalyst could be easily recovered and reused for at least six cycles without losing activating efficiency for $\mathrm{Cu}_{2} \mathrm{O}$.

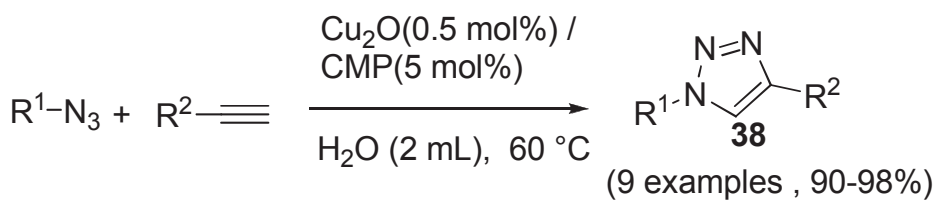

38a: $\mathrm{R}^{1}=\mathrm{C}_{6} \mathrm{H}_{5} \mathrm{CH}_{2^{-}}, \mathrm{R}^{2}=\mathrm{C}_{6} \mathrm{H}_{5} \mathrm{OCH}_{2^{-}}, 98 \%$ 38e: $\mathrm{R}^{1}=4-\mathrm{O}_{2} \mathrm{NC}_{6} \mathrm{H}_{4} \mathrm{CH}_{2^{-}}, \mathrm{R}^{2}=4-\mathrm{CH}_{3} \mathrm{C}_{6} \mathrm{H}_{4^{-}}, 90 \%$

38b: $\mathrm{R}^{1}=\mathrm{C}_{6} \mathrm{H}_{5} \mathrm{CH}_{2^{-}}, \mathrm{R}^{2}=4-\mathrm{O}_{2} \mathrm{NC}_{6} \mathrm{H}_{4} \mathrm{OCH}_{2^{-}}, 91 \%$

38c: $\mathrm{R}^{1}=\mathrm{C}_{6} \mathrm{H}_{5} \mathrm{CH}_{2^{-}}, \mathrm{R}^{2}=4-\mathrm{ClC}_{6} \mathrm{H}_{4} \mathrm{OCH}_{2^{-}}, 95 \%$

38f: $\mathrm{R}^{1}=4-\mathrm{O}_{2} \mathrm{NC}_{6} \mathrm{H}_{4} \mathrm{CH}_{2^{-}}, \mathrm{R}^{2}=4-\mathrm{ClC}_{6} \mathrm{H}_{4} \mathrm{OCH}_{2^{-}}, 92 \%$

38g: $\mathrm{R}^{1}=\mathrm{C}_{6} \mathrm{H}_{5^{-}}, \mathrm{R}^{2}=4-\mathrm{ClC}_{6} \mathrm{H}_{4} \mathrm{OCH}_{2^{-}}, 94 \%$

38d: $\mathrm{R}^{1}=\mathrm{C}_{6} \mathrm{H}_{5} \mathrm{CH}_{2}-\mathrm{R}^{2}=4-\mathrm{CH}_{3} \mathrm{C}_{6} \mathrm{H}_{4}, 95 \%$

38h: $\mathrm{R}^{1}=\mathrm{C}_{6} \mathrm{H}_{5^{-}}, \mathrm{R}^{2}=4-\mathrm{CH}_{3} \mathrm{C}_{6} \mathrm{H}_{4^{-}}, 94 \%$

38h: $\mathrm{R}^{1}=\mathrm{C}_{6} \mathrm{H}_{5^{-}}, \mathrm{R}^{2}=\mathrm{C}_{6} \mathrm{H}_{5} \mathrm{OCH}_{2^{-}}, 98 \%$

Scheme 39. CMP promoted $\mathrm{Cu}_{2} \mathrm{O}$-catalyzed synthesis of triazoles.

\section{Conclusions}

The $\mathrm{Cu}(\mathrm{I})$-catalyzed 1,3-dipolar cycloaddition variant of Huisgen reaction has emerged as powerful tool in the synthetic organic chemistry, material chemistry, chemical biology and medicinal chemistry. But the elimination of trace quantities of homogeneous copper catalyst from the desired product is important especially in the pharmaceutical industry. This problem can be circumvented by the use of heterogeneous copper catalyst and a number of these catalysts has been synthesized and used for the synthesis of 1,2,3-triazoles. The use of supported copper nanoparticles is environmentally benign, economical, the nanoparticles are easily available, and it avoids the contamination of the desired product with metal. Click chemistry has been a notable recent breakthrough and further research on copper nanoparticle-catalyzed click reaction variant may be useful for the efficient and green synthesis of novel compounds with wide potential in various fields.

\section{Abbreviations}

AFM = Atomic forced microscopy

AI MAS NMR = Adsorption isotherm-magic angle spinning-nuclear magnetic resonance AMWCNT $=$ Activated Multi-Walled Carbon Nanotubes

$\mathrm{APSiO}_{2}=$ Aminopropyl silica gel

3-APTES = 3-Aminopropyltriethoxysilane 
AQ2-Cu(II)/APSiO 2 = 1,4-Dihydroxyanthraquinone-copper(II) nanoparticles immobilized on aminopropyl silica gel

Cell-CuI $=$ Cuprous iodide on cellulose

chit- $\mathrm{CuSO}_{4}=$ Copper sulfate immobilized on chitosan

$\mathrm{Cu}-\mathrm{Al}_{2} \mathrm{O}_{3}=$ Alumina supported copper nanoparticles

$\mathrm{Cu}-\mathrm{CPSIL}=$ Cross-linked polymeric ionic liquid material-supported copper

$\mathrm{Cu}$-PSIL = Imidazolium-loaded Merrifield resin-supported copper

$\mathrm{Cu}(0)-\mathrm{Fe}_{3} \mathrm{O}_{4} @ \mathrm{SiO}_{2} / \mathrm{NH}_{2} \mathrm{cel}=$ Silica coated magnetic copper nanoparticles onto ethylene

diamine functionalized cellulose

CuNPs/MagSilica = Copper nanoparticles supported on silica coated maghemite

$\mathrm{CMP}=$ carboxymethylpullulans

(DHQD)2PHAL = Hydroquinidine-1,4-phthalazinediyl diether

DMTSF $=$ Dimethyl(methylthio) sulfonium tetrafluoroborate

EDAX = Energy dispersive X-ray analysis

$\mathrm{EDS}=$ Energy dispersive spectroscopy (EDS) analysis

$\mathrm{EDX}=$ Energy dispersive $\mathrm{X}$-ray spectroscopy

$\mathrm{EPR}=$ Electron paramagnetic resonance

ESI-MS= Electrospray ionization mass spectrometry

FT-IR $=$ Fourier transform infrared spectroscopy

$\mathrm{GO} / \mathrm{Pim} / \mathrm{Cu}=$ Copper ions in a graphene oxide/poly(vinyl imidazole)

HRTEM = High resolution transmission electron microscopy

ICP-AES = Inductively coupled plasma atomic emission spectroscopy

ICP-MS = Inductively coupled plasma-mass spectrometry

MTT = 3-(4,5-Dimethylthiazol-2-yl)-2,5-diphenyltetrazolium bromide

nano-FGT-Cu catalyst $=$ Nano ferrite-glutathione-copper catalyst

MNP@PDMA-Cu = Copper sulphate onto multi-layered poly(2-dimethylaminoethyl

acrylamide)-coated magnetic nanoparticles

PSIL = Imidazolium-loaded polymeric support

PVP-coated $\mathrm{Cu}_{2} \mathrm{O}$-NPs = Polyvinylpyrrolidone coated copper (I) oxide nanoparticle

PXRD = Powder X-ray differaction

PANI@CuI-NPs = Copper $(\mathrm{I})$ iodide nanoparticles on polyaniline

$\mathrm{P}[\mathrm{imCu} / \mathrm{IL}][\mathrm{Cl}]=$ Poly $(1-$ vinyl imidazole

co-ionic liquid)

SEM = Scanning electron microscopy

SMA = Styrene-co-maleic anhydride

$\mathrm{SMI}=$ Styrene-co-maleimide

$\mathrm{T}(\mathrm{o}-\mathrm{Cl}) \mathrm{PPCu}=$ Meso-tetrakis(o-chlorophenyl)porphyrinato]copper(II) nanoparticles

$\mathrm{T}(\mathrm{o}-\mathrm{Cl}) \mathrm{PPCu}$-AMWCNT = Meso-tetrakis(o-chlorophenyl)porphyrinato]copper(II) nanoparticles onto Activated Multi-Walled Carbon Nanotubes.

TEM = Transmission electron microscopy 
TGA $=$ Thermogravimetric analysis

$\mathrm{XPS}=\mathrm{X}$-ray photoelectron spectroscopy

$\mathrm{XRD}=\mathrm{X}$-ray diffraction $(\mathrm{XRD})$

\section{References}

1. Kolb, H. C.; Finn, M. G.; Sharpless, K. B. Angew. Chem. 2001, 113, 2056. http://dx.doi.org/10.1002/1521-3757(20010601)113:11<2056::AIDANGE2056>3.0.CO;2-W

2. Kolb, H. C.; Sharpless, K. B. Drug Discov. Today 2003, 8, 1128. http://dx.doi.org/10.1016/S1359-6446(03)02933-7

3. Rostovtsev, V. V.; Green, L. G.; Fokin, V. V.; Sharpless, K. B. Angew. Chem. Int. Ed. 2002, 41, 2596. http://dx.doi.org/10.1002/1521-3773(20020715)41:14<2596::AID-ANIE2596>3.0.CO;2-4

4. Tornoe, C. W.; Christensen, C.; Meldal, M. J. Org. Chem. 2002, 67, 3057. http://dx.doi.org/10.1021/jo011148j

5. Droumaguet, C. L.; Wang, C.; Wang, Q. Chem. Soc. Rev. 2010, 39, 1233. http://dx.doi.org/10.1039/B901975H

6. Kappe, C. O.; Eycken, E. V. Chem. Soc. Rev. 2010, 39, 1280. http://dx.doi.org/10.1039/B901973C

7. Nakamura, T.; Terashima, T.; Ogata, K.; Fukuzawa, S. I. Org. Lett. 2011, 13, 620. http://dx.doi.org/10.1021/ol102858u

8. Huisgen, R. Angew. Chem. Int. Ed. Engl. 1963, 2, 565. http://dx.doi.org/10.1002/anie.196305651

9. Gothelf, K. V.; Jorgensen, K. A. Chem. Rev. 1998, 98, 863. http://dx.doi.org/10.1021/cr970324e

10. Huisgen, R.; Padwa, A. Wiley, New York 1984, 1, 1.

11. Dervaux, B.; Duprez, F. E. Chem. Sci. 2012, 3, 959. http://dx.doi.org/10.1039/C2SC00848C

12. Chmielewski, M.; Jurczak, J. Tetrahedron Lett. 2004, 45, 6007. http://dx.doi.org/10.1016/j.tetlet.2004.06.037

13. Huisgen, R. Pure Appl. Chem. 1989, 61, 613. http://dx.doi.org/10.1351/pac198961040613

14. Agalave, S. G.; Maujan, S. R.; Pore, V. S. Chem. Asian. J. 2011, 6, 2696. http://dx.doi.org/10.1002/asia.201100432

15. Pokhodylo, N.; Shyyka, O.; Matiychuk, V. Med. Chem. Res. 2014, 23, 2426. http://dx.doi.org/10.1007/s00044-013-0841-8

16. Lazrek, H. B.; Taourirte, M.; Oulih, T.; Barascut, J. L.; Imbach, J. L.; Pannecouque, C.; Witrouw, M.; De Clercq, E. Nucleosides, Nucleotides and Nucleic Acids 2001, 12, 1949. 
http://dx.doi.org/10.1081/NCN-100108325

17. Yan, S. J.; Liu, Y. J.; Chen, Y. L.; Liu, L.; Lin, J. Bioorg. Med. Chem. Lett. 2010, 20, 5225. http://dx.doi.org/10.1016/j.bmcl.2010.06.141

18. Shanmugavelan, P.; Nagarajan, S.; Kumar, M. S.; Ponnuswamy, A.; Yogeeswari, P.; Sriram, D. Bioorg. Med. Chem. Lett. 2011, 21, 7273.

http://dx.doi.org/10.1016/j.bmcl.2011.10.048

19. Jordao, A. K.; Afonso, P. P.; Ferreira, V. F.; de Souza, M. C. B. V.; Almeida, M. C. B.; Beltrame, C. O.; Paiva, D. P.; Wardell, S. M. S. V.; Tiekink, E. R. T.; Damaso, C. R.; Cunha, A. C. Eur. J. Med. Chem. 2009, 44, 3777.

http://dx.doi.org/10.1016/j.ejmech.2009.04.046

20. Kharb, R.; Yar, M. S.; Sharma, P. C. Curr. Med. Chem. 2011, 18, 3265. http://dx.doi.org/10.2174/092986711796391615

21. Holla, B. S.; Karthikeyan, M. S.; Poojary, B.; Akberali, P. M.; Kumari, N. S. Eur. J. Med. Chem. 2005, 40, 1173. http://dx.doi.org/10.1016/j.ejmech.2005.02.013

22. Sabarinathan, N.; Sridharan, S.; Antony, S. A. Int. J. Chem. Tech. Res. 2015, 7, 2573.

23. Anil Kumar, B. S. P.; Reddy, H. V.; Madhav, B.; Ramesh, K.; Nageswar, Y. V. D. Tetrahedron Lett. 2012, 53, 4595. http://dx.doi.org/10.1016/j.tetlet.2012.06.077

24. Wang, X. L.; Wan, K.; Zhou, C. H. J. Med. Chem. 2010, 45, 4631. http://dx.doi.org/10.1016/j.ejmech.2010.07.031

25. Droumaguet, C. L.; Wang, C.; Wang, Q. Chem. Soc. Rev. 2010, 39, 1233. http://dx.doi.org/10.1039/B901975H

26. Shao, C.; Zhu, R.; Luo, S.; Zhang, Q.; Wang, X.; Hu, Y. Tetrahedron Lett. 2011, 52, 3782. http://dx.doi.org/10.1016/j.tetlet.2011.05.061

27. Kim, S. H.; Choi, H. S.; Kim, J.; Lee, S. J.; Quang, D. T.; Kim, J. S. Org. Lett. 2010, 12, 560. http://dx.doi.org/10.1021/o1902743s

28. Kantheti, S.; Narayan, R.; Raju, K. V. S. N. RSC Adv. 2015, 5, 3687. http://dx.doi.org/10.1039/C4RA12739K

29. Anastas, P. T.; Eghbali, N. Chem. Soc. Rev. 2010, 39, 301. http://dx.doi.org/10.1039/B918763B

30. Goesmannand, H.; Feldmann, C. Angew. Chem. Int. Ed. 2010, 49, 1362. http://dx.doi.org/10.1002/anie.200903053

31. Jia, C. J.; Schuth, F. Phys. Chem. Chem. Phys. 2011, 13, 2457. http://dx.doi.org/10.1039/c0cp02680h

32. Zahmakıran, M.; Ozkar, S. Nanoscale. 2011, 3, 3462. http://dx.doi.org/10.1039/c1nr10201j

33. Astruc, D.; Liang, L.; Rapakousiou, A.; Ruiz, J. Acc. Chem. Res. 2012, 45, 630. http://dx.doi.org/10.1021/ar200235m 
34. Horne, W. S.; Yadav, M. K.; Stout, C. D.; Ghadiri, M. R. J. Am. Chem. Soc. 2004, 126, 15366. http://dx.doi.org/10.1021/ja0450408

35. Gawande, M. B.; Bonifacio, V. D. B.; Luqul, R.; Branco, P. S.; Varma, R. S. Chem. Soc. Rev. 2013, 42, 5522. http://dx.doi.org/10.1039/c3es60025d

36. Liang, L.; Astruc, D. Coord. Chem. Rev. 2011, 255, 2933. http://dx.doi.org/10.1016/j.ccr.2011.06.028

37. Meldal, M.; Tornoe, C. W. Chem. Rev. 2008, 108, 2952. http://dx.doi.org/10.1021/cr0783479

38. Harmand, L.; Lescure, M. H.; Candelon, N.; Duttine, M.; Lastecoveres, D.; Vincent, J. M. Tetrahedron Lett. 2012, 53, 1417. http://dx.doi.org/10.1016/j.tetlet.2012.01.035

39. Coperet, C.; Chabanas, M.; Arroman, R. P. S.; Basset, J. M. Angew. Chem. Int. Ed. 2003, $42,156$. http://dx.doi.org/10.1002/anie.200390072

40. Basset, J. M.; Choplin, A. J. Mol. Catal. 1993, 21, 95. http://dx.doi.org/10.1016/0304-5102(93)80113-9

41. Alonso, F.; Moglie, Y.; Radivoy, G. Acc. Chem. Res. 2015, 48, 2516. http://dx.doi.org/10.1021/acs.accounts.5b00293

42. Lefebvre, F.; Basset, J. M. J. Mol. Catal. A: Chem. 1999, 146, 3. http://dx.doi.org/10.1016/S1381-1169(99)00104-1

43. Lipshutz, B. H.; Taft, B. R. Angew. Chem. 2006, 118, 8415. http://dx.doi.org/10.1002/ange.200603726

44. Chassaing, S.; Sido, A. S. S.; Alix, A.; Kumarraja, M.; Pale, P.; Sommer, J. Chem. Eur. J. 2008, 14, 6713. http://dx.doi.org/10.1002/chem.200800479

45. Yamaguchi, K.; Oishi, T.; Katayama, T.; Mizuno, N. Chem. Eur. J. 2009, 15, 10464. http://dx.doi.org/10.1002/chem.200901444

46. Katayama, T.; Kamata, K.; Yamaguchi, K.; Mizuno, N. Chem. Sus. Chem. 2009, 2, 59. http://dx.doi.org/10.1002/cssc.200800202

47. Park, I. S.; Kwon, M. S.; Kim, Y.; Lee, J. S.; Park, J. Org. Lett. 2008, 10, 497. http://dx.doi.org/10.1021/ol702790w

48. Miao, T.; Wang, L. Synthesis 2008, 3, 363.

49. Coelho, A.; Diz, P.; CaamaÇo, O.; Sotelo, E. Adv. Synth. Catal. 2010, 352, 1179. http://dx.doi.org/10.1002/adsc.200900680

50. Bonami, L.; Camp, W. V.; Rijckegem, D. V.; Prez, F. E. D. Macromol. Rapid Commun. 2009, 30, 34.

http://dx.doi.org/10.1002/marc.200800607 
51. Girard, C.; Onen, E.; Aufort, M.; Beauviere, S.; Samson, E.; Herscovici, J. Org. Lett. 2006, $8,1689$. http://dx.doi.org/10.1021/o10602831

52. Chan, T. R.; Fokin, V. V. QSAR Comb. Sci. 2007, 26, 1274. http://dx.doi.org/10.1002/qsar.200740131

53. Sirion, U.; Bae, Y. J.; Lee, B. S.; Chi, D. Y. Synlett 2008, 15, 2326.

54. Chtchigrovsky, M.; Primo, A.; Gonzalez, P.; Molvinger, K.; Robitzer, M.; Quignard, F.; Taran, F. Angew. Chem. 2009, 121, 6030. http://dx.doi.org/10.1002/ange.200901309

55. Sharghi, H.; Beyzavi, M. H.; Safavi, A.; Doroodmand, M. M.; Khalifeh, R. Adv. Synth. Catal. 2009, 351, 2391. http://dx.doi.org/10.1002/adsc.200900353

56. Horak, D.; Babic, M.; Mackova, H.; Benes, M. J. J. Sep. Sci. 2007, 30, 1751. http://dx.doi.org/10.1002/jssc.200700088

57. Laurent, S.; Forge, D.; Port, M.; Roch, A.; Robic, C.; Elst, L. V.; Muller, R. N. Chem. Rev. 2008, 108, 2064. http://dx.doi.org/10.1021/cr068445e

58. Yan, N.; Xiao, C.; Kou, Y. Coord. Chem. Rev. 2010, 254, 1179. http://dx.doi.org/10.1016/j.ccr.2010.02.015

59. Albadi, J.; Keshavarz, M.; Shirini, F.; Vafaie-nezhad, M. Catal. Commun. 2012, 27, 17. http://dx.doi.org/10.1016/j.catcom.2012.05.023

60. Kantam, M. L.; Jaya, V. S.; Sreedhar, B.; Rao, M. M.; Choudary, B. M. J. Mol. Catal. A: Chem. 2006, 256, 273. http://dx.doi.org/10.1016/j.molcata.2006.04.054

61. Sharghi, H.; Khalifeh, R.; Doroodmand, M. M. Adv. Synth. Catal. 2009, 351, 207. http://dx.doi.org/10.1002/adsc.200800612

62. Shargi, H., Beyzavi, M. H.; Safavi, A.; Doroodmand, M. M.; Khalifeh, R. Adv. Synth. Catal. 2009, 351, 2391. http://dx.doi.org/10.1002/adsc.200900353

63. Alonso, F.; Moglie, Y.; Radivoy, G.; Miguel Y. Adv. Synth. Catal. 2010, 352, 3208. http://dx.doi.org/10.1002/adsc.201000637

64. Wang, Y.; Liu, J.; Xia, C. Adv. Synth. Catal. 2011, 353, 1534. http://dx.doi.org/10.1002/adsc.201000868

65. Alonso, F.; Moglie, Y.; Radivoy, G.; Miguel, Y. J. Org. Chem. 2011, 70, 8394 http://dx.doi.org/10.1021/jo2016339

66. Alonso, F.; Moglie, Y.; Radivoyb, G.; Yus, M. Org. Biomol. Chem. 2011, 9, 6385. http://dx.doi.org/10.1039/c1ob05735a

67. Wan, L.; Cai, C. Catal. Lett. 2012, 142, 1134. http://dx.doi.org/10.1007/s10562-012-0880-7

68. Nasir Baig, R. B.; Varma, R. S. Green Chem. 2012, 14, 625. 
http://dx.doi.org/10.1039/c2gc16301b

69. Sharghi, H.; Khoshnood, A.; Doroodmand, M. M.; Khalifeh, R. J. Iran Chem. Soc. 2012, 9, 231.

http://dx.doi.org/10.1007/s13738-011-0046-3

70. Kumar, B. S. P. A.; Reddy K. H. V.; Madhav, B.; Ramesh, K.; Nageswar, Y. V. D. Tetrahedron Lett. 2012, 53, 4595.

http://dx.doi.org/10.1016/j.tetlet.2012.06.077

71. Sharghi, H.; Ebrahimpourmoghaddam, S.; Doroodmand, M. M.; Purkhosrow, A. Asian J. Org. Chem. 2012, 1, 377.

http://dx.doi.org/10.1002/ajoc.201200012

72. Alonso, F.; Moglie, Y.; Radivoyb, G.; Yus, M. Heterocycles 2012, 84, 1033. http://dx.doi.org/10.3987/COM-11-S(P)81

73. Xiong, X.; Cai, L. Catal. Sci. Technol. 2013, 3, 1301. http://dx.doi.org/10.1039/c3cy20680g

74. Nador, F.; Volpe, M. A.; Alonso, F.; Feldhoff, A.; Kirschning, A.; Radivoy, G. Appl. Catal., A 2013, 455, 39.

75. Gholinejad, M.; Jeddi, N. ACS Sustainable chem. Eng. 2014, 2, 2658. http://dx.doi.org/10.1021/sc500395b

76. Chavan, P. V.; Pandit, K. S.; Desai, U. V.; Kulkarni, M. A.; Wadgaonkar, P. P. RSC Adv. 2014, 4, 42137.

http://dx.doi.org/10.1039/C4RA05080K

77. Roy, S.; Chatterjee, T.; Pramanic, M.; Roy, A. P.; Bhaumik, A.; Islam, Sk. M. J. Mol. Catal. A: Chem. 2014, 386, 78.

http://dx.doi.org/10.1016/j.molcata.2014.01.027

78. Hashemi, E.; Beheshtiha, Y. S.; Ahmadi, S.; Heravi, M. M.; Transition Met. Chem. 2014, 39, 593. http://dx.doi.org/10.1007/s11243-014-9838-5

79. Pourjavadi, A.; Hosseini, S. H.; Zohrehb, N.; Bennettc, C. RSc Adv. 2014, 4, 46418. http://dx.doi.org/10.1039/C4RA07817A

80. Naeimi, H.; Nejadshafiee, V. New J. Chem. 2014, 38, 5429. http://dx.doi.org/10.1039/C4NJ00909F

81. Pourjavadi, A.; Tajbakhsh, M.; Farhangb, M.; Hosseinia, S. H. New J. Chem. 2015, 39, 4591. http://dx.doi.org/10.1039/C4NJ02134G

82. Mirsafaei, R.; Heravi, M. M.; Ahmadi, S.; Moslemin, M. H.; Hosseinnejad, T. J. Mol. Catal. A: Chem. 2015, 402, 100.

http://dx.doi.org/10.1016/j.molcata.2015.03.006

83. Saadat, S.; Nazari, S.; Afshari, M.; Shahabi, M.; Keshavarz, M. Orient. J. Chem. 2015, 31, 1005 .

http://dx.doi.org/10.13005/ojc/310248 
84. Pourjavadi, A.; Safaie, N.; Hosseini, S. H.; Bennett, C. Appl. Organometal. Chem. 2015, 29, 601 . http://dx.doi.org/10.1002/aoc.3336

85. Lua, J.; Maa, E. Q.; Liub, Y. H.; Lia, Y. M.; Moa, L. P.; Zhanga, Z. H. RSC Adv. 2015, 5, 59167.

http://dx.doi.org/10.1039/C5RA09517D

86. Zohreh, N.; Hosseini, S. H.; Pourjavadi, A.; Bennett, C. Appl. Organometal. Chem. 2016, 30,73 .

http://dx.doi.org/10.1002/aoc.3398

87. Bhardwaj, M.; Jamwal, B.; Paul, S. Catal. Lett. 2016, 146, 629.

http://dx.doi.org/10.1007/s10562-015-1672-7

88. Raut, D.; Wankhede, K.; Vaidya, V.; Bhilare, S.; Darwatkar, N.; Deorukhkar, A.; Trivedi, G.; Salunkhe, M. Catal. Comm. 2009, 10, 1240.

http://dx.doi.org/10.1016/j.catcom.2009.01.027

89. Zhang, Z.; Dong, C.; Yang, C.; Hu, D.; Long, J.; Wang, L.; Li, H.; Chen, Y.; Kongthe, D. Adv. Synth. Catal. 2010, 352, 1600.

http://dx.doi.org/10.1002/adsc.201000206

90. Fernandez, A. M.; Mucoz, M. O.; Jaramillo, J. L.; Mateo, F. H.; Gonzaleza, F. S. Adv. Synth. Catal. 2010, 352, 3306.

http://dx.doi.org/10.1002/adsc.201000530

91. Borah, B. J.; Dutta, D.; Saikia, P. P.; Baruab, N. C.; Dutta, D. K. Green Chem. 2011, 13, 3453.

http://dx.doi.org/10.1039/c1gc16021d

92. Hudson, R.; Li, C.; Moores, A. Green Chem. 2012, 14, 622.

http://dx.doi.org/10.1039/c2gc16421c

93. Kumar, S.; Datta, K. K. R.; Raol, T. S.; Raghavan, K. V.; Eswaramoorthy, M.; Reddy B. V. S. J. Nanosci. Nanotech. 2013, 13, 3136. http://dx.doi.org/10.1166/jnn.2013.7343

94. Nasir Baig, R. B.; Varma, R. S. Green chem. 2013, 15, 1839. http://dx.doi.org/10.1039/c3gc40401c

95. Ali, A. A.; Chetia, M.; Saikia, P. J.; Sarma, D. RSC Adv. 2014, 4, 64388. http://dx.doi.org/10.1039/C4RA12572J

96. Hajlaoui, K.; Hamadi, B. N.; Msaddek, M. Catal. Lett. 2015, 145, 1246. http://dx.doi.org/10.1039/C4RA12572J

97. Zhang, W.; Ren, B.; Jiang, Y.; Hu, Z. RSC Adv. 2015, 5, 12043. http://dx.doi.org/10.1039/C4RA14813D 


\section{Authors' Biographies}

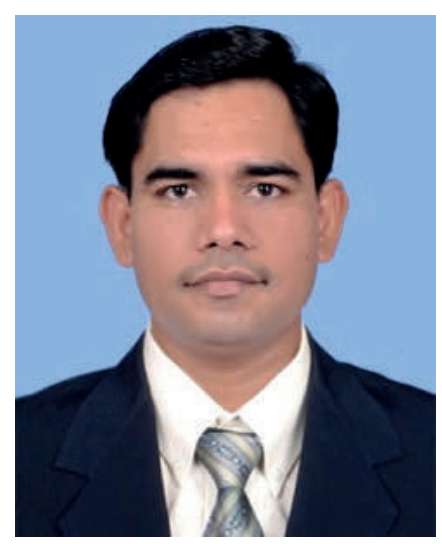

Kashmiri Lal was born in Haryana, India in 1981. He has obtained his M.Sc. (2004) and Ph.D. (2014) in chemistry from Guru Jambheshwar University of Science \& Technology, Hisar, India. He is working as Assistant Professor in the Department of Chemistry, Guru Jambheshwar University of Science \& Technology, Hisar, India, since 2006. His research interest includes the synthesis of biologically active 1,2,3-triazoles, dendrimers, and ion recognition.

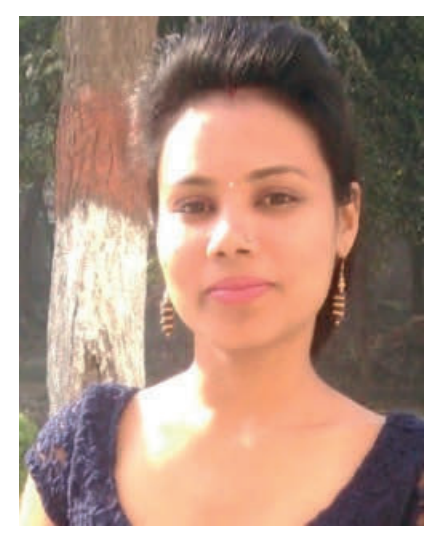

Poonam Rani was born in Haryana, India, in 1988. She obtained her M.Sc. (Chemistry) from Maharishi Dayanand University, Rohtak, Haryana, India, in 2011. Currently, she is doing doctoral research in Chemistry under the supervision of Dr. Kashmiri Lal at Guru Jambheshwar University of Science and Technology, Hisar. Her research focuses on synthesis and ion recognition studies of 1,2,3-triazoles. 